\title{
Geothermal potential, chemical characteristic and utilization of groundwater in Serbia
}

Tanja Petrović Pantić ( $\nabla$ tanjapetrovic.hg@gmail.com )

Geological Survey of Serbia https://orcid.org/0000-0003-1456-6913

Katarina Atanasković Samolov

Geological Survey of Serbia

Jana Štrbački

University of Belgrade Faculty of Mining and Geology

Milan Tomić

Geological Survey of Serbia

\section{Research Article}

Keywords: geothermal database, geothermal resources, geothermal potential, hydrochemistry, hierarchical cluster analysis, Serbia

Posted Date: June 14th, 2021

DOI: https://doi.org/10.21203/rs.3.rs-185122/v1

License: (c) (1) This work is licensed under a Creative Commons Attribution 4.0 International License. Read Full License 


\section{Abstract}

In order to collect and unify data about all geothermal resources in Serbia, a database is formed. The database allows us to perceive the geothermal resources of Serbia and their potential for utilization. Based on the data available in the geothermal database, the estimated temperatures of reservoirs, heat power, and geothermal energy utilization were calculated. The database contains 293 objects (springs, boreholes) registered at 160 locations with groundwater temperature in the range between $20^{\circ} \mathrm{C}$ and $111^{\circ} \mathrm{C}$. The maximum expected temperature of the reservoir is $146^{\circ} \mathrm{C}$ (according to the $\mathrm{SiO}_{2}$ geothermometer). Some thermal water is cooled while mixed with cold, shallow water. Geothermal resources are mostly used for balneology and recreation, and less for heating, water supply, bottling, fish and animal farms, agriculture, and technical water. $26 \%$ of all geothermal resources is used by the local population or has not been used at all. The annual utilization of geothermal energy for direct heat is 1507 $\mathrm{TJ} / \mathrm{yr}$, and the estimated capacity of geothermal energy in Serbia is $111 \mathrm{MWt}$. The results of analytical work were presented in the form of maps with a geological and hydrogeological background. Thermal waters are mostly registrated in the area of Tertiary magmatism. The three geothermal potential areas are identified: Pannonian basin-Vojvodina Province, Mačva-Srem and area from Jošanička Banja to Vranjska Banja (southern Serbia). Based on chemical analyses, four hydrochemical facies are distinguished. Thermal water mainly belongs to $\mathrm{NaHCO}_{3}$ or $\mathrm{CaMgHCO}_{3}$ hydrochemical facies, usually depending on the primary aquifer: karst, karst-fissured, intergranular or fissured.

\section{Highlights}

- The geothermal database contains 293 objects registered at 160 locations.

- The highest temperature of geothermal resources is $111^{\circ} \mathrm{C}$, maximum expected $146^{\circ} \mathrm{C}$.

- The annual utilization of geothermal energy for direct heat is $1507 \mathrm{TJ} / \mathrm{yr}$.

- The estimated capacity of geothermal energy in Serbia is $111 \mathrm{MWt}$.

- Thermal water mainly belongs to $\mathrm{NaHCO}_{3}$ or $\mathrm{CaMgHCO}_{3}$ hydrochemical facies.

\section{Introduction}

Renewable energy is of the utmost importance in the world in these trying times, when climate change is more intensive and the consequences of pollution can be found in the air, water, and soil. Geothermal resources specifically could be of great importance within energy usage development. The thermal and mineral water has a long history of usage on the territory of Serbia. The majority of thermal and mineral groundwater is used for balneology. The first records of geothermal resource utilization, i.e. thermal waters, date back to the ancient world. The archaeological proof is dating from the Roman period, and later, the Ottoman Empire. Most spas in Serbia date back from that period, and many baths were since neglected. The presence of minerals makes these waters curative, thus were commonly used for baths and therapies. Consequently, geothermal waters are more frequently referred to as thermomineral waters that have been used for medicinal purposes. The first mention of their utilization is from 1856 for 16 
thermal and mineral waters (Lindenmayer; 1856), while the first preserved publication on healing water research in Serbia dates from 1922 (Leko et al;1922). The research into thermal water as geothermal energy was published at the end of the XIX century in the book "Groundwater" (Radovanović; 1898). In the second half of the 20th century, research on thermal and mineral water gained increased attention, and many new boreholes were drilled, resulting in the building of new spa centers. Extensive research was carried out in the 1970s and 1980s when over 100 boreholes were drilled. The deepest groundwater borehole in the Pannonian Basin is 2520 m deep (Milivojević and Martinović; 2000, Golušin et al,. 2010). Based on previous research, 159 thermal springs $\left(t>15^{\circ} \mathrm{C}\right.$ ) (Milivojević and Martinović; 2000 , Ristić et al,-. 2019) and 60 commercial spas were mentioned (Valjarević et al,. 2018, Ristić et al,. 2019).

In Vojvodina Province (northern Serbia), in the period between 1969 and 1996, 73 hydrothermal boreholes with $62.847 \mathrm{~m}$ were drilled (Bašić et al,. 2005, Košić et al,. 2011). Vojvodina Province is the most explored area regarding geothermal energy. The Geothermal atlas of Vojvodina is the result of long-standing research (Martinović et al;. 2010).

This study analyze the occurrence and spatial distribution of geothermal springs/wells of Serbia in relation to geological settings, geotectonic units and type of aquifer. The connection between aquifer type and dominant chemical composition of thermal water was taken into consideration. Hierarchical cluster analysis was applied in order to understand chemical differences between water samples.

Based on previous research on geothermal energy, it is determined that the territory of Serbia is characterized by significant geothermal potential and the possibilities of its exploitation. Currently, the exploitation of geothermal energy in Serbia is very low considering the abundance of resource locations. Geothermal resources are mostly used for bathing and swimming, but these are very important alternative resources for sustainable energy development in Serbia (Golušin et al,. 2010). Creating the geothermal database enables us to perceive the resources we dispose of and their exploitation potential, which will be presented in this paper. The database contains information about groundwater with a temperature of at least $20^{\circ} \mathrm{C}$ at the outflow, as a usual lower limit temperature, which defines thermal water (Aleksandrov 1932, Ovčinkov 1963, Jordan and Weder 1988, Filipović and Dimitrijević 1991, Porowski 2017).

\section{Geology And Hydrogeology, And Geothermal Background}

Geological structures of the territory of Serbia are based on geotectonic units (Dimitrijević; 2002). Generally, the following units are identified: Pannonian Basin in the north, Carpatho-Balkanides from east to west, Serbo-Macedonian Massif, Vardar Zone, and the Dinarides. Based on the terrain concept, the central part of the Balkan peninsula and the central part of Serbia are further subdivided into different units (Karamata et al;. 1992, Karamata and Krstić,.1996, Jelenković et al,. 2008).

Hydrogeological regions of Serbia (Filipović et al,. 2005, Petrović Pantić et al,. 2015) have a similar area as following geotectonic units: Pannonian Basin on the north, then from east to west: Dacian basin 
region, the Carpatho-Balkanides, the Serbian crystalline core region, the Šumadija-Kopaonik-Kosovo region, and the Internal Dinarides region.

From a hydrogeological point of view, based on the lithostratigraphic units, the following types of aquifers are present (Fig. 1):

- Intergranular (porous): Quaternary and Tertiary

- Karst

- Karst-fissured

- Fissured (fractured)

Terrains without aquifers are marked as water impermeable rocks.

The intergranular type of aquifer is widely spread on the surface of the territory of Serbia. This type of aquifer comprises of Quaternary sediments (alluvial is dominant) and Tertiary sediments (Neogene basins). Alluvial sediments are not the primary aquifer in thermal waters. Thermal water can be formed in several layers within the Neogene basin (confined aquifer or semi-confined). In that case, the hydrochemical zonality is present, so as the depth increases, the mineralization and the temperature increase, and thus the chemical properties of water change. However, the Neogene basin can be the second aquifer of thermal water.

The Province of Vojvodina has significant geothermal potential as part of the Pannonian Basin. Geothermal potential of Pannonian basin is well known (Horváth et al. 2015; Nádor et al. 2012; Rman et al. 2015a; Tóth et al. 2016, Rman et al. 2020). In some parts of the Pannonian Basin, the Neogene complex is composed of sandstone, shale, marls, limestone, clay, sand, and gravel with depth over $3 \mathrm{~km}$. Magmatic and volcanic rocks can be found here as well, alongside their pyroclastic equivalents (Martinović et al;. 2010).

In the Serbian part of the Pannonian Basin, the 4 hydrogeological systems are identified according to their depth (Aksin et al;. 1991, Milojević and Martinović; 2000, Martinović et al;. 2010):

I hydrogeological system is from the surface to upper Pontian (Quaternary and Lower Pliocene) up to 2 km deep. In shallow parts, the lacustrine sands and gravel can be found, and in deeper parts clay-sandymarly sediments are present. The aquifer thickness is between 10 and 20 meters. The depth of this complex is between 300 and 500 meters, depending on trenches and horst within the tectonic. In the first hydrogeological system, the highest temperature of the Pannonian Basin (Vrbica $82^{\circ} \mathrm{C}$ ) is registered. Geothermal waters are $\mathrm{Na}-\mathrm{HCO}_{3}$, while TDS can be usually about $1 \mathrm{~g} / \mathrm{L}$.

Il hydrogeological system is composed of sandstone and marl of Lower Pliocene and Pannonian. There is a presence of tight- fissure aquifer. This system is characterized by limited aquifer properties, which is reflected in the low yield of thermal water. The average temperature of water in the second hydrogeological system is from 28 to $68^{\circ} \mathrm{C}$ (boreholes in Uljma), highly-mineralized, $\mathrm{Na}-\mathrm{HCO}_{3}-\mathrm{Cl}$. 
The aquifer of the III hydrogeological system consists of Miocene sandstone, limestone, basalt conglomerate, and breccia. There is a presence of the tight- fissure- karst aquifers, which are formed with a semi-opened hydrogeological structure. The groundwater temperature can be higher than $120^{\circ} \mathrm{C}$ in the aquifer of the Pannonian Basin reservoir (Goldscheider et al. 2010) The temperature of water in Vojvodina Province, part of the Pannonian Basin, is between 22 and $72^{\circ} \mathrm{C}$, and the thermal water is highly mineralized (TDS>1 g/L). In certain parts of the complex, the oil and gas deposits are present. The complex thickness is between 1000 and $1500 \mathrm{~m}$. Geothermal waters are of $\mathrm{Na}-\mathrm{HCO}_{3}$ to $\mathrm{Ca}-\mathrm{HCO}_{3}$.

The aquifer of the IV hydrogeological system is composed of fractured and cavernous Triassic limestone and dolomite. The water temperature ranges from $23-57^{\circ} \mathrm{C}$ (Inđija, Ležimir, Kupinovo), $\mathrm{Na}-\mathrm{Cl}$ to $\mathrm{Na}-\mathrm{HCO}_{3}$. TDS is usually lower than $1 \mathrm{~g} / \mathrm{L}$.

The similar cross-section is defined in Hungary where Quaternary sediments are on the top, then Upper Pannonian and Lower Pannonian sediments, Miocene, and Mesozoic, Paleogene basement (Juhasz 1992; Toth and Almasi 2001, Buday et al. 2015)

Geothermal resources occur in the other Neogene basins in Serbia. The very productive aquifer is in Mačva (western Serbia) (Martinović and Milivojević,. 2000), where highly karstified Triassic limestone (karst aquifer) lie beneath deep Neogene and Quaternary sediments (the maximum thickness is up to $1500 \mathrm{~m}$ ). The paleo relief is made of paleo granites, which gives us the clarification of thermal anomaly in this area. The heat flow of Mačva is up to $120 \mathrm{~mW} / \mathrm{m}^{2}$ (Perić and Milivojević; 1990, Martinović and Milivojević; 2000) which makes that part of Serbia very productive in terms of geothermal energy exploitation. The highest temperature is registered in Bogatić $\left(80^{\circ} \mathrm{C}\right)$. Besides temperature, a significant amount of groundwater can be captured in this region ( $245 \mathrm{l} / \mathrm{s}$ from five boreholes) (Martinović and Milivojević; 2000). The spread of Triassic limestones under Neogene sediments is registered in the southern Srem (Inđija, Ruma) where water with temperature up to $60^{\circ} \mathrm{C}$ is captured, while Triassic limestones occur on the surface of the Fruška Gora Mountain (Vrdnik). Geothermal zone Mačva-Srem has wider area, where thermal water is also registered in Bosnia and Hercegovina, in Dvorovi and Slobomir (Miošić and Samardžić 2016)

Karst aquifer is composed of carbonate rocks, mainly limestone and dolomite in eastern and western Serbia (Carpatho-Balkanids and Dinarides). Oscillations of yield and temperature are characteristic of karst springs. The perfect example is the "Glavno vrelo" karst spring in Niška Banja, where temperature varies from 13 to $39^{\circ} \mathrm{C}$, yield $35-5000 \mathrm{l} / \mathrm{s}$ (Protić; 1995). This indicates that there is a mix of cold and thermal waters. Low mineralization of thermal water and dominant presence of $\mathrm{Ca}$ and $\mathrm{HCO}_{3}$ is common for the karst aquifer. In the Carpatho-Balkanides (eastern Serbia), thermal springs are linked with the foldthrust belt between Supergeticum and Geticum. However, the main source of heating of karst springs is a mostly undiscovered magmatic intrusion. In the Dinarides (western Serbia), fissured and karstified Mesozoic limestone is present, as well as ophiolitic melange with limestone and dolomite, therefore thermal springs mainly occur in the contact zone. 
In the Dinarides, the groundwater flows throughout karst channels and fissures, thus the aquifer is defined as a karst-fissured aquifer. It is present in the terrain with intensive rock changes: conglomerates, sandstones, marls, dolomite and limestone, shale, volcanic rocks.

The fissured aquifer is comprised of intrusive and effusive rocks, metamorphic rocks (crystalline schist), and solid sediment rocks (sandstone, marl, conglomerate, breccia, and some carbonate rocks). It is dominant in the hydrogeology region Serbian Crystalline Core (Petrović Pantić et al; 2015). The thermal water is mainly the consequence of Tertiary volcanic and magmatic activity. The highest temperature of groundwater is obtained from these aquifers (Vranjska Banja, Kuršumlijska, Sijarinska, Novopazarska). Low-thermal water with a presence of natural $\mathrm{CO}_{2}$ usually occurs in metamorphic rocks (Bukovička Banja, Palanački kiseljak, Vrnjačka Banja). Geological structures, fractures and faults, have an important role in heat flow, as well as water recharge and discharge.

Synthesis of presented aquifers is given in the table 1.

Water impermeable rocks are composed of schist, argiloschist, gneiss, flysch, and meta-rocks of Cambrium, Ordovicium, and Paleozoic. These rocks are widespread in the southern part of Serbia.

\section{Geothermal Background}

The main parameter for defining the geothermal potential of some areas is heat flow density. The average heat flow density of Earth is $82 \mathrm{~mW} / \mathrm{m}^{2}$ (Bertani and Lund; 2013). The value of heat flow density is higher than $100 \mathrm{~mW} / \mathrm{m}^{2}$ (Milivojević and Martinović; 2000) in the following geological units:

Pannonian Basin, Serbo-Macedonian Massif and Vardar Zone (Fig 2). In the Pannonian Basin, the mean value of heat flow is about $100 \mathrm{~mW} / \mathrm{m}^{2}$, ranging from 50 to $130 \mathrm{~mW} / \mathrm{m}^{2}$ (Horvath et al. 2015). The values of the terrestrial heat flow density in Serbia are higher than the average values in continental Europe (Milivojević and Martinović; 2000).

The high geothermal potential is in close connection with Tertiary magmatism (Milivojević 1993). Tertiary magmatism is dominant in the geotectonic units of Vardar Zone and Serbo-Macedonian Massif, while tFhe youngest intrusive rock is detected in southern Serbia (Cvetković et al,. 2004), and this could be the reason for higher heat flow density in that area. Besides, Badenian volcanics occur in the northern part of Serbia (Cvetković et al. 2004), which explain high temperature of groundwater in north Vojvodina and the value of flow density above $110 \mathrm{~mW} / \mathrm{m}^{2}$. In Fig 2 . it is obvious that the highest temperature of thermal water occur in the area of the high terrestrial heat flow, which coincides with the areas of Tertiary magmatism. Area with high geothermal potential extends from NW to SE.

The geothermal potential is also linked to lithosphere thickness. In the Pannonian Basin, the thickness is around 25 to $29 \mathrm{~km}$, in Serbo-Macedonian Massif-is $32 \mathrm{~km}$, in Carpatho-Balkanides is from 33-38 km, while in the area of the Dinarides it is 40 km (Dragašević et al;. 1990, Milivojević; 1993, Martinović and Milivojević; 2010). 
Many thermal water wells and springs form from the carbonate aquifer between deep Neogene sediments, and in the area with Tertiary magmatism (Mačva-Srem), where heat transfers by conduction, hence the geothermal gradient increases with well depth.

Groundwaters with the highest temperature are obtained from magmatic and metamorphic rocks in southern Serbia (Serbo-Macedonian Massif), where heat transfer depends on geological structure and permeability of rocks (fissured type of aquifer). For example in Sijarinska Banja spa temperature of thermal water is $71^{\circ} \mathrm{C}$ from shallow well at depth of $8 \mathrm{~m}$, while temperature from borehole at depth of $1232 \mathrm{~m}$ is $78^{\circ} \mathrm{C}$ (Petrović Pantić et al. 2015, Todorović et al. 2015).

\section{Research Methods}

The geothermal database has been created according to the data from previous geothermal research in Serbia. The research covers geothermal resources of Serbian territory, according to available documentation and publications.

The database contains the following fields:

- Location (coordinate, place, name of source, alternative name, type of object (spring/borehole))

- Borehole depth, year of drilling, range $(m)$ of the screen or open hole, number of screen, depth of aquifer $(m)$, aquifer media type, lithology of the aquifer, stratigraphic unit, capacity $(1 / s)$, reserves $(\mathrm{l} / \mathrm{s})$

- Chemical analysis (temperature of water $\left({ }^{\circ} \mathrm{C}\right)$, temperature class, $\mathrm{pH}, \mathrm{Ep}(\mathrm{mS} / \mathrm{cm})$, mineralization $(\mathrm{mg} / \mathrm{l})$, dry residue at $180^{\circ} \mathrm{C}(\mathrm{mg} / \mathrm{l})$, degree of hardness $\left({ }^{\circ} \mathrm{dH}\right), \mathrm{Na}(\mathrm{mg} / \mathrm{l}), \mathrm{K}(\mathrm{mg} / \mathrm{l}), \mathrm{Ca}(\mathrm{mg} / \mathrm{l}), \mathrm{Mg}$ (mg/l), $\mathrm{HCO}_{3}(\mathrm{mg} / \mathrm{l}), \mathrm{SO}_{4}(\mathrm{mg} / \mathrm{l}), \mathrm{Cl}(\mathrm{mg} / \mathrm{l}), \mathrm{Al}(\mathrm{mg} / \mathrm{l}), \mathrm{As}(\mathrm{mg} / \mathrm{l}), \mathrm{B}(\mathrm{mg} / \mathrm{l}), \mathrm{Br}(\mathrm{mg} / \mathrm{l}), \mathrm{Cs}(\mu \mathrm{g} / \mathrm{l}), \mathrm{F}$ (mg/l), Fe (mg/l), I (mg/l), Ge ( $\mu \mathrm{g} / \mathrm{l}), \mathrm{Li}(\mathrm{mg} / \mathrm{l}), \mathrm{Mn}(\mathrm{mg} / \mathrm{l}), \mathrm{Rb}(\mathrm{mg} / \mathrm{l}), \mathrm{Sr}(\mathrm{mg} / \mathrm{l}), \mathrm{Zn}(\mathrm{mg} / \mathrm{l}), \mathrm{U}(\mu \mathrm{g} / \mathrm{l}), \mathrm{V}$ $(\mu \mathrm{g} / \mathrm{l}), \mathrm{W}(\mu \mathrm{g} / \mathrm{l}), \mathrm{NH}_{4}(\mathrm{mg} / \mathrm{l}), \mathrm{NO}_{2}(\mathrm{mg} / \mathrm{l}), \mathrm{NO}_{3}(\mathrm{mg} / \mathrm{l}), \mathrm{SiO}_{2}(\mathrm{mg} / \mathrm{l})$, date of analyses, laboratory

- owner of objects, type of usage, data source

Based on available data the thermal water usage, heat power, and usage of geothermal energy were calculated according to the following equations:

Capacity $(\mathrm{MWt})=$ Flow rate (Inlet temperature - Outlet temperature $) \times 0.004184$

Energy use $(\mathrm{TJ} / \mathrm{yr})=$ Average flow rate (Inlet temperature - Outlet temperature) $\times 0.1319$

Capacity factor $=($ Energy use $/$ Capacity $) \times 0.03171$

The capacity factor must be lower than or equal to 1.00 and it is usually lower since objects do not operate at $100 \%$ of capacity all year.

The database contains 135 chemical analyses of thermal water. Chemical analyses contain main cations and anions, pH, TDS, EC, and other elements. Analyses were predominantly carried out by accredited 
laboratories from Serbia (Institute of public health) regarding QA/QC protocol, in the past 20 years. Cations $\left(\mathrm{Na}^{+}, \mathrm{K}^{+}, \mathrm{Ca}^{+}, \mathrm{Mg}^{+}\right)$were determined by atomic absorption spectroscopy (AAS), whereas anion $\left(\mathrm{HCO}_{3}{ }^{2-}, \mathrm{SO}_{2}{ }^{-}, \mathrm{Cl}^{-}\right)$were determined by conventional analytical methods. To avoid inaccurate results, the ion balance was used. Analyses with ion balance $<10 \%$ were accepted. The ion balance is in the range from -8.2 to $10 \%$ (average $0,5 \%$ ). The lack of TDS data was resolved using cations and anions. TDS was calculated based on the chemical analyses as a sum of concentrations (in $\mathrm{mg} / \mathrm{L}$ ) of $0.6($ Alk $)+\mathrm{Na}+\mathrm{K}+\mathrm{Ca}+\mathrm{Mg}+\mathrm{Cl}+\mathrm{SO}_{4}+\mathrm{SiO}_{2}+\left(\mathrm{NO}_{3}-\mathrm{N}\right)+\mathrm{F}$.

In order to classify the analyzed thermal waters into hydrochemical facies, hierarchical cluster analysis (HCA) was applied. The initial dataset consisted of: 135 groundwater samples and 12 physical and chemical parameters $\left(\mathrm{pH}\right.$, temperature, $\mathrm{Na}, \mathrm{K}, \mathrm{Mg}, \mathrm{Ca}, \mathrm{Cl}, \mathrm{SO} 4, \mathrm{HCO}, \mathrm{Mn}, \mathrm{Fe}$ and $\mathrm{F}$; temperature in $\left[{ }^{\circ} \mathrm{C}\right.$ ], all concentrations in $[\mathrm{mg} / \mathrm{L}])$. The analysis was performed with standardized data (z-score values), using Euclidean distance, as a measure of similarity, and Ward's method, as a linkage method. Visual inspection of the resulted dendrogram provided the insight into underlying structure of the data, i.e. which samples form coherent clusters.

Chemical geothermometers (silica and cation) are used to estimate the reservoir temperature of thermal waters based on the chemical composition. Silica $\left(\mathrm{SiO}_{2}\right)$ geothermometers are based on the solubility of quartz, chalcedony, or amorphous silica in water, while cation geothermometers are based on the solubility of cations $\left(\mathrm{Na}^{+}, \mathrm{K}^{+}, \mathrm{Ca}^{2+}, \mathrm{Mg}^{2+}\right)$ in water. The following geothermometers were applied:

$\mathrm{SiO}_{2}$ (quartz), (Fournier, 1977)

$\mathrm{SiO}_{2}$ (quartz), (Fournier, 1977)

$\mathrm{SiO}_{2}$ (quartz), (Fournier and

Potter, 1982)

$\mathrm{SiO}_{2}$ (quartz), (Fournier and

Potter, 1982)

$\mathrm{SiO}_{2}$ (calcedone), (Arnorsson et al, 1983)

$\mathrm{SiO}_{2}$ (calcedone), (Fournier,

1977)

Na-K, (Giggenbach, 1988)

Na-K,(Nieva and Nieva, 1987)

Na-K, (Founier, 1979)

Na-K, (Arnorsson et al, 1983)

K-Mg, (Fournier and

Truesdell, 1973)

$\begin{array}{rlr}t & =\frac{1309}{5.19-\log \left(\mathrm{SiO}_{2}\right)}-273.15 & \text { Eq.1 } \\ t & =\frac{1522}{5.75-\log \left(\mathrm{SiO}_{2}\right)}-273.15 & \text { Eq. } 2 \\ -42.2+0.28831\left(\mathrm{SiO}_{2}\right)-3.6686 \times 10^{-4}\left(\mathrm{SiO}_{2}\right)^{2}+3.1665 \times 10^{-7}(\mathrm{SiO} 2)^{3}+77.034 \log \left(\mathrm{SiO}_{2}\right) & \text { Eq.3 } \\ -53.5+0.11236\left(\mathrm{SiO}_{2}\right)-0.5559 \times 10^{-4}\left(\mathrm{SiO}_{2}\right)^{2}+0.1772 \times 10^{-7}\left(\mathrm{SiO}_{2}\right)^{3}+88.39 \log \left(\mathrm{SiO}_{2}\right) & \text { Eq.4 } \\ t & =\frac{1112}{4.91-\log \left(\mathrm{SiO}_{2}\right)}-273.15 & \text { Eq.5 } \\ t & =\frac{1032}{4.69-\log \left(\mathrm{SiO} O_{2}\right)}-273.15 & \text { Eq.6 } \\ t & =\frac{1390}{1.75+\log (\mathrm{Na} / \mathrm{K})}-273.15 & \text { Eq.7 } \\ t & =\frac{1178}{1.47+\log (\mathrm{Na} / \mathrm{K})}-273.15 & \text { Eq.8 } \\ t & =\frac{1217}{1.483+\log (\mathrm{Na} / \mathrm{K})}-273.15 & \text { Eq.9 } \\ t & =\frac{933}{0.933+\log (\mathrm{Na} / \mathrm{K})}-273.15 & \text { Eq.10 } \\ t & =\frac{4410}{14-\log \left(\mathrm{K}^{2} / \mathrm{Mg}\right)}-273.15 & \text { Eq.11 }\end{array}$

Eq. 1

Eq. 2

Eq.3

Eq.4

Eq. 5

Eq.6

Eq. 7

Eq.8

Eq.9

q. 10

-11

For the map view, software ArcGIS (ESRI) was used. 


\section{Results And Discussions: \\ 5.1 Utilization of geothermal resources of Serbia}

The geothermal database of Serbia contains 293 data of thermal water from springs, boreholes, and wells distributed in 160 localities with a temperature between 20 and $111^{\circ} \mathrm{C}$. Serbia has more localities with thermal water and information about them that will be included in the database in the future. More than half of the groundwater samples are in the temperature range between $20-30^{\circ} \mathrm{C}$ (Fig. 3 ). The mean value of the temperature of geothermal resources is $38^{\circ} \mathrm{C}$, and the median is $33^{\circ} \mathrm{C}$. The highest temperature was measured in Vranjska Banja (4 samples). Besides temperature, the very important factor is the capacity of the geothermal spring/borehole. The highest capacity potential is present in carbonate aquifer, specifically in karstified limestone between deep Neogene sediments (Mačva) and granitic rocks and their metamorphic zones (Vranjska Banja, Sijarinska Banja).

According to the classification of geothermal resources (Muffler and Cataldi; 1978), thermal waters in Serbia are of low-enthalpy resources water $\left(<90^{\circ} \mathrm{C}\right)$; however, water in Vranjska Banja is the only intermediate-enthalpy resource $\left(90-150^{\circ} \mathrm{C}\right)$, and possibly suitable for the production of electricity. Depending on the temperature, the low-enthalpy resources can be utilized directly, for space heating and cooling, bathing, swimming, balneology, agriculture (greenhouses and animal farms), aquaculture (fish ponds), industry. Heat pumps for heating and cooling can also utilize them. According to the way of utilization (Milenić et al;. 2010), two types of low-enthalpy resources are proposed: sub(hydro)geothermal $\left(\mathrm{t}<30^{\circ} \mathrm{C}\right)$ and (hydro)geothermal $\left(\mathrm{t}=30-100^{\circ} \mathrm{C}\right)$. Groundwater with a temperature between $5^{\circ} \mathrm{C}$ and $30^{\circ} \mathrm{C}$ is used with geothermal pumps, mainly for heating and cooling objects.

Geothermal resources are mostly of traditional use in Serbia, for balneotherapy and in swimming pools. Water with positive balneological effect is classified as healing water based on its physical and chemical properties. In addition, geothermal resources are used for heating the spa objects, medical centers, and hotels. However, many of these systems are worn-out and work partially. The most developed spa centers to date are Vrnjačka Banja, Bukovička Banja, Prolom Banja, Lukovska Banja, Sokobanja, Vrujci, Koviljača, Kanjiža.

The system for direct heating exists in Vranjska Banja and Bogatić (school, ambulance, kindergarten, hotel, pools, etc). In Bogatić, borehole BB-1 ( $\left.Q=25 \mathrm{I} / \mathrm{s}, \mathrm{t}=75^{\circ} \mathrm{C}\right)$ was used for heating, while in Vranjska Banja geothermal water was united $\left(Q=100 \mathrm{l} / \mathrm{s}, \mathrm{t}=87-100^{\circ} \mathrm{C}\right)$ and distributed to other objects. Thermal water is used for greenhouses in some locations (area of Mačva, Kočura, Vranjska Banja), for drying cereals (Bački Petrovac), for animal farms (Banatsko Veliko Selo, Mokrin, Vranjska Banja), and industry (Kula, Vranjska Banja). Thermal water is also used for bottling (with temperature up to $30^{\circ} \mathrm{C}$, Minaqua, Bivoda, AquaGala, Vujić, Vrnjci, Prolom), for water supply (groundwater source Vreoci for the water supply of Lazarevac town) and as technical water. Thermal water often has also an outflow for public use (Prolom Banja, Gornja Trepča, Vranjska Banja, etc.). 
Nearly $25 \%$ of groundwater from the database is not in use. The unused water is a consequence of many boreholes in Vojvodina (northern Serbia) which were primarily drilled for oil but closed soon afterwards. These waters could be used for swimming pools, healing, heating, and cooling, depending on their temperature, quality, and quantity.

Using geothermal energy instead of fossil fuels is of utmost importance when considering environmental impact. Direct usage of geothermal resources of five spas in the NE part of Serbia (Prolom, Ribarska, Sijarinska, Bujanovačka, and Vranjska Banja) is $300 \mathrm{TJ} / \mathrm{yr}$ or $83 \mathrm{GWh}$, and it can alternate the 7138.15 tons of equaling oil or 19197.35 tons of equaling coal. The use of geothermal energy instead of oil would stop the emission of $6307.5 \mathrm{t} \mathrm{CO}_{2}$ in the air, and accordingly, the coal would stop the emission of $6530.5 \mathrm{t}$ $\mathrm{CO}_{2}$ (Petrović Pantić; 2014).

Analyzing the use of geothermal energy in Serbia, the total installed thermal capacity in 2010 was 100.8 $\mathrm{MWt}$, while the annual geothermal energy use in Serbia was 1,410 TJ/yr with a capacity factor of 0.44 (Martinović and Milivojević; 2000).

In 2015 , the total installed capacity was calculated to $104.55 \mathrm{MWt}$, while $1,714 \mathrm{TJ} / \mathrm{yr}$ is for usage with a capacity factor of 0.52 (Oudech and Đokić; 2015).

Since 2019, the total installed heat capacity is $111 \mathrm{MWt}$, and the energy use is $1,507 \mathrm{TJ} / \mathrm{yr}$, with a capacity factor of 0.53 (Table 1). The flow rate of all boreholes and springs is up to $911 \mathrm{l} / \mathrm{s}$. The most prospective location according to the flow rate is Vranjska Banja (circa $100 \mathrm{l} / \mathrm{s}$ ), Bogatić (84 I/s), Debrc (75 l/s), Sokobanja (75 l/s), and Pribojska (58 l/s).

The new result is higher than in the aforementioned years, however, this table contains 80 objects (wells/springs) compared to 2010 (55 objects) and 2015 (65 objects). The data from wells (objects) that are no longer in use are excluded and the data on water quantity and temperature are updated based on recent documentation. If the maximum heating potential of 80 objects was used (outlet temperature of thermal water $12^{\circ} \mathrm{C}$ ), then the heat capacity would be $187.5 \mathrm{MWt}$.

The use of heat pumps has been increasing in recent years. They are commonly used for heating and cooling buildings, residential complexes, and office space. The low groundwater temperatures that are up to $30^{\circ} \mathrm{C}$ are used for these purposes. During 2018,100 heat pumps were installed with a total capacity of 15.59 MW that produces 34.37 GWth/yr (Oudech and Đokić; 2019)

\subsection{Hydrogeochemistry of geothermal resources of Serbia}

The chemical composition of water is a consequence of the mineralogical composition of the aquifer (Chebotarev 1955, Garrels and Christ 1965, Garrels and McKenzie 1967).

The database contains 135 chemical analyses of thermal water. There are 30 chemical analyses of groundwater from an intergranular aquifer, 46 chemical analyses from fissured, 37 from karst, and 22 
from karst-fissured aquifers (Table 2). Generally, the groundwater is slightly acidic to alkaline with $\mathrm{pH}$ value in the range between 6.4 and 9.5. $\mathrm{pH}$ higher than 8 is found in a few samples from sandstone, metasandstone, while alkaline water $(\mathrm{pH}>9)$ is found in samples from andesites, granodiorites, chloriteepidote schists. Slightly acidic thermal waters are waters with natural carbon dioxide.

TDS is in the range between 149.6 and $6857.9 \mathrm{mg} / \mathrm{L}$, the median is $516 \mathrm{mg} / \mathrm{L}$ (Table 2). The mineral water (TDS>1 $\mathrm{g} / \mathrm{L}$ ) is usually present in the fissured aquifer and intergranular aquifer. Thermal water from the intergranular aquifer has a TDS median of $1049.5 \mathrm{mg} / \mathrm{L}$ (maximum $4161.6 \mathrm{mg} / \mathrm{L}$ ), and thermal water from the fissured aquifer has a TDS median of 1297.4 (maximum $6857.9 \mathrm{mg} / \mathrm{L}$ ). $33 \%$ of all samples are mineral water according to TDS $>1 \mathrm{~g} / \mathrm{L}$, respectively thermo-mineral water $\left(\mathrm{t}>20^{\circ} \mathrm{C}\right)$. Low mineralized water is dominant in karst-fissured and karst aquifer, where the TDS median is from 320.4 to $384.3 \mathrm{mg} / \mathrm{L}$. Despite this, the lowest TDS is noticed in thermal water from andesites (Prolom Banja). TDS represents the concentration of dissolved ions in groundwaters, and mostly depends on main cations and anions. However, with the application of the Pearson correlation coefficient (Table 3), it is concluded that TDS is in correlation with $\mathrm{Na}$ in thermal water for all aquifers ( $r=0.78$ to 0.99 ), while TDS is in correlation with $\mathrm{K}$ only in the karst-fissured aquifer ( $r=0.97)$. TDS is in strong correlation with all anions in thermal water from the karst-fissured aquifer ( $r=0.88$ to 0.98 ), as well as with $\mathrm{HCO}_{3}$ of a karst aquifer ( $\left.r=0.94\right)$. In groundwater of intergranular aquifer, TDS is in correlation with $\mathrm{Cl}(\mathrm{r}=0.81), \mathrm{HCO}_{3}(\mathrm{r}=0.80)$ as well as $\mathrm{Na}$ $(r=0.99)$. Mostly, the groundwater samples of intergranular aquifer belong to the Pannonian basin, so the correlation between TDS and $\mathrm{Na}$ and $\mathrm{Cl}$ is a consequence of salt mineral (halite) in rocks (ex Pannonian sea). The correlation between $\mathrm{Ca}$ and $\mathrm{Mg}$ with TDS is noticed in water from karst and karst-fissured aquifer. This can be explained as the influence of covered intrusion on the temperature of groundwater as well as influence on chemical composition in these aquifers. An example of this is geothermal water in Mačva, where $\mathrm{Na}$ is a dominant cation, while the primary aquifer is in karst rocks and Neogene sediments, which proves deep intrusion (plutonic) caused by geothermal anomaly in this area.

According to the anion composition, $\mathrm{HCO}_{3}$ is predominant (Fig. 4a), while sulfate thermal waters are generally rare in Serbia. The highest concentration of $\mathrm{Cl}$ is dominant in many thermal water samples from Vojvodina, and in several samples of mineralized water in Serbia. Based on a cation composition, $\mathrm{Ca}$ and CaMg is predominant in western and eastern Serbia, where karst and karst-fissured aquifers are present (Fig. 4b). $\mathrm{Na}$ is predominant in northern Serbia in the Pannonian basin (intergranular aquifer), and in the central and southern Serbia, Serbo-Macedonian Massif (fissure aquifer). Cation composition of groundwater is the reflection of the main rock composition of an aquifer.

Thermal waters were classified based on the results of the hierarchical cluster analysis (HCA). The two main groups of groundwater were identified - A (82 samples) and B (53 samples), each divided into two subgroups - A1 (58 samples) and A2 (24 samples); B1 (7 samples) and B2 (46 samples). Using the nonparametric Kruskal-Wallis test, it was found that the selected groups, i.e. subgroups, differ significantly $(p<0.05)$, in terms of median values of analyzed physical and chemical parameters (with the exception of $\mathrm{Mg}$ and $\mathrm{Ca}$, whose values do not differ significantly). The extracted clusters were interpreted as hydrochemical facies and they were plotted on the Piper diagram (Fig. 5a). 
The main features of the group B are elevated mineralization and elevated temperature (median values: $2688 \mathrm{mg} / \mathrm{L}$ and $47^{\circ} \mathrm{C}$, respectively), while groundwaters from the group $A$ are mostly low mineralized (median TDS value: $361 \mathrm{mg} / \mathrm{L}$ and $26^{\circ} \mathrm{C}$ ). Accordingly, thermal waters belonging to group $B$ are characterized by elevated concentrations of the most macro and micro components, with the exception of calcium, which is the dominant cation in the subgroup A1 (Fig. 5a), and the nitrate ion, also characteristic for the subgroup A1. Subgroup A2 features alkaline waters (median pH value 8), belonging to $\mathrm{Na}-\mathrm{HCO}_{3}$ facies and with the highest median concentrations of arsenic $(0.01 \mathrm{mg} / \mathrm{L})$. Subgroup B1 contains the fewest number of samples (only seven) and these are the waters with the highest mineral content (TDS values ranging from 2506 to $6858 \mathrm{mg} / \mathrm{L}$ ). Maximal concentrations of major ions $\mathrm{Na}^{+}(2445$ $\mathrm{mg} / \mathrm{L}), \mathrm{Cl}^{-}(4080 \mathrm{mg} / \mathrm{L})$ and $\mathrm{SO}_{4}{ }^{2-}(2550 \mathrm{mg} / \mathrm{L})$, as well as micro components manganese $(4 \mathrm{mg} / \mathrm{L})$, iron $(70 \mathrm{mg} / \mathrm{L})$, ammonia $(106 \mathrm{mg} / \mathrm{L})$ and boron $(23 \mathrm{mg} / \mathrm{L})$ were registered in thermal waters from this subgroup. The pronounced chloride and sulphate content classify some of these waters into $\mathrm{NaCl}$ and $\mathrm{NaKClSO}_{4}$ facies (Fig. 5a). Thermal waters from the subgroup B2 are characterized by the highest temperatures (median: $48^{\circ} \mathrm{C}$, max: $111^{\circ} \mathrm{C}$ ), and by elevated concentrations of fluoride (median: 2.8 $\mathrm{mg} / \mathrm{L}$ ) and silica (median: $60 \mathrm{mg} / \mathrm{L}$ ).

The classification of thermal waters depending on the type of aquifer is also presented on the Piper diagram (Fig. 5b). The following hydrochemical facies stand out: $\mathrm{CaHCO}_{3}, \mathrm{CaMgHCO}_{3}, \mathrm{NaCl}$, mixed $\mathrm{CaNaHCO}_{3}, \mathrm{NaHCO}_{3}$.

$\mathrm{CaMgHCO}_{3}$ facia is dominant in groundwater of karst-fissured aquifer and karst aquifer. The groundwater of fissured aquifer mainly belongs to $\mathrm{NaHCO}_{3}$ facies, while in some samples it belongs to $\mathrm{NaCl}$, mixed $\mathrm{CaNaHCO}_{3}, \mathrm{CaHCO}_{3} . \mathrm{NaHCO}_{3}$ facia is also dominant in the groundwater of intergranular aquifer.

The subgroup A1 mostly consists waters from karst and karst-fissured type of aquifer comparing the two Piper diagrams with the same samples but different classification. In the subgroup A2, thermal water from intergranular type of aquifer dominates. The subgroup B1 is made of water from fractured and intergranular type of aquifer (I and II hydrogeological system) where geological settings are very complex. However, the subgroup B2 consist waters from fractured type of aquifer, but rarely from karst or intergranular type of aquifer.

\subsection{Geothermometers}

Chemical composition of thermal water have an important role in geothermal exploration, and one of these roles is to estimate the reservoir temperature.

In this paper, the $\mathrm{SiO}_{2}$ and cation geothermometers are used for the calculation of the maximum expected temperature of reservoirs. $\mathrm{SiO}_{2}$ geothermometers are applied on 75 thermal waters samples, while cation geothermometers are applied on 134 samples. The database does not contain a concentration of $\mathrm{SiO}_{2}$ 
for all available samples, especially in groundwater samples from Vojvodina, while data of main cations and anions are available.

Using Na-K geothermometers, the maximum expected temperatures are obtained in waters from the karst aquifer. Also, cation geothermometers give the value over $500{ }^{\circ} \mathrm{C}$ (Table 4), which is not a reliable result. According to the previous research, the application of Na-K geothermometers on groundwater in the Serbian Crystalline Core region resulted in unrealistically high values (Petrović Pantić et al;.

2015). Equation 11 shows a lower temperature than measured. Contents of $\mathrm{Mg}$ are rather low in samples, so the values obtained from $\mathrm{K}-\mathrm{Mg}$ geothermometers cannot be accepted (Petrović Pantić et al;. 2015).

By analyzing all geothermometers, the $\mathrm{SiO}_{2}$ geothermometers gave reliable results. Comparing quartz with chalcedony geothermometer, the chalcedony geothermometer shows a lower temperature than quartz, almost the same as the measured temperature. There are minor temperature differences between different quartz geothermometers (eq 1 , eq 2 , eq 3 , and eq 4), usually from 1 to $3^{\circ} \mathrm{C}$ difference (table 4 ).

The highest temperatures of groundwater are registered in the fissured and intergranular aquifers. Based on $\mathrm{SiO} 2$ geothermometers, the highest expected temperature is in Vranjska Banja $\left(118-146^{\circ} \mathrm{C}\right)$, where higher water temperature is measured at the wellhead $80-105^{\circ} \mathrm{C}$, then Mataruška $\left(134^{\circ} \mathrm{C}\right)$, Bukovička Banja $\left(72-135^{\circ} \mathrm{C}\right)$, Jošanička $\left(128^{\circ} \mathrm{C}\right)$, Bujanovačka $\left(123^{\circ} \mathrm{C}\right)$, Mačva $\left(69-115^{\circ} \mathrm{C}\right)$, Sijarinska $\left(115^{\circ} \mathrm{C}\right)$. The highest temperatures are from the SE part of Serbia to the NW direction (Fig. 6). According to the geothermometers, high temperature is expected in the area of Bukovička Banja, spa with numerous boreholes and springs, where the maximum measured temperature is at the wellhead $37.5^{\circ} \mathrm{C}$ and in the area of Mataruška Banja, where the highest water temperature is measured at the wellhead $48^{\circ} \mathrm{C}$.

$\mathrm{Na}-\mathrm{K}-\mathrm{Mg}^{0.5}$ triangular diagram (Giggenbach; 1986) show that the highest expected temperature cannot be more than $180^{\circ} \mathrm{C}$ (Fig. 7). The groundwater samples with lower temperature $\left(<30^{\circ} \mathrm{C}\right)$ are mostly found in or near the zone of immature waters, which indicates mixing with cold water. Some groundwater from Vojvodina/Pannonian Basin reaches full equilibrium (Palić, Kanjiža, Janošik), as well as two samples from a different region (Prolom and Rajčinovića). All other samples are in the zone of partial equilibrium with the host rocks.

\section{Conclusion}

Based on the measured outlet temperature of groundwater, quantity of groundwater, geology, and hydrogeology of the terrain, heat flow density, and geothermometry, the territory of Serbia has significant geothermal potential, as consequence of Tertiary magmatism. The three areas with elevated geothermal potentional are identified: Vojvodina Province/Pannonian Basin, especially on the northern border; Mačva-Srem area; the area from Jošanička Banja to Vranjska Banja-

A total of 293 objects (springs, boreholes) were included in the geothermal database, which mostly used for balneology and recreation, and less for heating, bottling, heat pumps, animal farms, agriculture, and as technical water. Many geothermal objects $(25 \%)$ are not in use. 
The total installed capacity in Serbia is $111 \mathrm{MWt}$ (without heat pump), while the annual geothermal energy use is $1507 \mathrm{TJ} / \mathrm{yr}$ with a capacity factor of 0.52 .

The chemical composition of thermal water varies and depends on geological conditions. Different hydrochemical facies of geothermal resources, mineralization, and the presence of minerals and gases provide different healing purposes. Dominant anion is $\mathrm{HCO}_{3}$, while cation composition varies and these variations depend on the rocks in which the waters are formed. According to HCA two groups stand out: A group with low mineralized groundwater and median temperature $26^{\circ} \mathrm{C}$, and $\mathrm{B}$ group with elevated mineralization and elevated temperature (median $47^{\circ} \mathrm{C}$ ). Based on $\mathrm{SiO}_{2}$ geothermometer, the highest expected temperature of reservoir is $146^{\circ} \mathrm{C}$.

Modern spas will certainly have a positive impact on tourism development, better health, and well-being. Furthermore, the utilization of geothermal resources will improve the economy by using thermal water for greenhouses, animal farms, fish ponds, industry, and bottling. In general, it will contribute to a better standard, more jobs, and sustainable communities. Using geothermal energy for heating instead of fossil fuels would reduce $\mathrm{CO}_{2}$ emissions, which would have a positive effect on climate change and an increase in energy efficiency.

The database will be regularly updated in the future. More thermal boreholes will be added to the database. The overall aim is to gain insight into available resources and improve the possibility of their utilization. Great quantities of geothermal resources remain unused due to insufficient exploration, political and legal relations, policy, permit procedures, and unresolved ownerships as a major issue. There is no doubt that geothermal resources should be better utilized and the formed database is of great importance for potential investments.

\section{Declarations}

\section{Acknowledgments:}

This paper is a result of the project: "Collection, updating and building database about geothermal resources of Republic of Serbia" supported by the Government of Republic of Serbia, Ministry of Mining and Energy, GeoERA project, funding from the European Union's Horizon 2020 research and innovation programme under grant agreement No 731166.

Funding - the Government of Republic of Serbia, Ministry of Mining and Energy, and GeoERA project, cofunded from the European Union's Horizon 2020 research and innovation programme under grant agreement No 731166, supported the research.

Conflicts of interest/Competing interests - The authors declare that they have no known competing financial interest or personal relationships that could have appeared to influence the work reported in this paper. 
Availability of data and material the data that support the findings of this paper are available on request. Restrictions apply to the availability of these data, which were used for this study. Data are available from the corresponding author with the permission of Ministry of Mining and Energy, and Geological Survey of Serbia.

Code availability (software application or custom code) Not applicable

Authors' contributions TPP developed the concept and designed the manuscript. KAS and MT were involved in the data collection and data analysis. TPP contributed to the interpretation of data and results with KAS and MT. KAS participated in the design of the manuscript. TPP wrote the final draft. All authors read and approved the final manuscript.

\section{References}

1. Aleksandrov VA (1932) Klasifikacija mineraljnih vod. Osnovi kurortologiji. T.1, Gosmedizdat, 133137

2. Aksin V, Marinović $Đ$, Vugrines $J$ (1991) Exploration and production of oil crude oil and gas in Yugoslav part of Pannonian basin. In (ed. Karamata S.) Geodynamic evolution of the Pannonian Basin, Proceedings of the international symposium, Belgrade, 309-329

3. Arnórsson S, Gunnlaugsson E, Svavarsson H (1983) The chemistry of geothermal waters in Iceland III. Chemical geothermometry in geothermal investigations. Geochim. Cosmochim. Acta 1983; 47; 567-577, https://doi.org/10.1016/0016-7037(83)90278-8

4. Bašić $\bigoplus$, Petrović J, Marić M (2005) Possibilities for utilization of energy potentials of geothermal waters in AP Vojvodina, Prometej; $205 p$

5. Bertani R, Lund J (2013) Chap. 9. Geothermal in World energy resources. World Energy Council;

6. Buday T, Szűcs P, Kozák M, Püspöki Z, McIntosh RW, Bódi E, Bálint B, Bulátkó K (2015) Sustainability aspects of thermal water production in the region of Hajduszoboszlo-Debrecen, Hungary. Environ Earth Sci 74:7511-7521. DOI 10.1007/s12665-014-3983-1

7. Cvetković V, Prelević D, Downes H, Jovanović M, Vaselli O, Pécskay Z (2004) Origin and geodynamic significance of Tertiary postcollisional basaltic magmatism in Serbia (central Balkan Peninsula), Lithos; 73:161-186

8. Chebotarev II (1955) Metamorphism of natural waters on the crust of weathering: Geochim. et Cosmochim Acta v 8:22-48; 137-170; 198-212

9. Dimitrijević M (2002) Geological map 1:2.000.000, Geological Atlas of Serbia, no 1. Republic foundation for geological investigations and Geological survey-Gemini

10. Dragašević T, Andrić B, Joksović P (1990) Structural Map of Mohorovičić discontinuity of Yugoslavia. Scale 1:500.000. Fed. Geol. Inst., Beograd

11. Filipović B, Dimitrijević N (1991) Mineral waters. Faculty of Mining and Geology, Belgrade; 
12. Filipović B, Krunić O, Lazić M (2005) Regional Hydrogeology of Serbia. Faculty of Mining and Geology. University in Belgrade

13. Fournier RO (1977) Chemical geothermometers and mixing model for geothermal systems. Geothermics; 5: 41-50

14. Fournier RO, Potter RW (1982) A revised and expanded silica (quartz) geothermometer. Geotherm Resourc Counc Bull 11:3-9

15. Fournier RO (1979) A revised equation for the Na-K geothermometer. Geotherm Resour Counc Trans 3:221-224

16. Fournier RO, Truesdell AH (1973) An empirical Na-K-Ca geothermometer for natural waters, Geochim. Cosmochim Acta 37:1255-1275

17. Garrels RM, Christ CL (1965) Solutions minerals and equilibria. New York, Harper and Row, $450 \mathrm{p}$

18. Garrels RM, Mackenzie FT (1967) Origin of the chemical compositions of some springs and in lakes in Equilibrium concepts in natural water chemistry. Am Chem Soc Advances in Chemistry Ser v 67:222-242

19. Giggenbach WF (1986) Graphical techniques for the evaluation of water/rock equilibration conditions by use of $\mathrm{Na}, \mathrm{K}, \mathrm{Mg}$ and $\mathrm{Ca}$ contents of discharge waters, Proceeding 8th Geothermal Workshop, 37-43. Labo. geology, ENS, Paris, ERAG on CNRS

20. Giggenbach WF (1988) Geothermal solute equilibria. Derivation of Na-K-Mg-Ca geoindicators. Geochim Cosmochim Acta 52(12):2749-2765. https://doi.org/10.1016/0016-7037(88)90143-3

21. Golušin M, Munitlak Ivanković $O$, Bagarić I, Vranješ S (2010) Exploitation of geothermal energy as a priority of sustainable energetic development in Serbia. Renew Sust Energ Rev 14:868-871. https://doi.org/10.1016/j.rser.2009.06.026

22. Goldscheider N, Mádl-Szőnyi J, Erőss A, Schill E (2010) Review: thermal water resources in carbonate rock aquifers. Hydrogeol J 18:1303-1318. https://doi.org/10.1007/s1004 0-010-0611-3

23. Horváth F, Musitz B, Balázs A, Végh A, Uhrine A, Nádor A, Koroknai B, Pap N, Tóth T, Wórum G (2015) Evolution of the Pannonian basin and its geothermal resources. Geothermics 53:328-352. https://doi.org/10.1016/j.geoth ermic s.2014.07.009

24. Jelenković R, Kostić A, Životić S, Ercegovac M (2008) Mineral resources of Serbia. Geol Carpath; 59(4):345-361

25. Jordan H, Weder HJ (1988) Hydrogeologie. Grundstoff-Verlag, Leipzig

26. Juhász G (1992) A pannóniai (s.I.) formációk téképezése az Alföldön: elterjedés, fácies és üledékes környezet. Földt Közlöny 122:133-165

27. Karamata S, Krstić B, Stojnov R (1992) Terranes from Adriatic to the Moesian Massif in the Central Part of the Balkan Peninsula. Terra Nova, 4, Abstract suppl. 2, Alcapa Symp., Gray, Graz, 1-36

28. Karamata S, Krstić B (1996) Terranes of Serbia and neighbouring areas. In: Knežević - Đorđević V and Krstić B. (Eds.): Terranes of Serbia. The formation of the geologic framework of Serbia and the 
adjacent region. Faculty of Mining and Geology, Comm. Geodynamics Serbian Academy of Science and Arts; $25-40$

29. Košić K, Pivac T, Romelić J, Lazić L, Stojanović V (2011) Characteristics of thermal-mineral waters in Backa region (Vojvodina) and their exploitation in spa tourism. Renew Sust Energ Rev 15:801807. https://doi.org/10.1016/j.rser.2010.09.004

30. Lindal B (1973) Industrial and other applications of geothermal energy. In: $\mathrm{HCH} A(e d)$ Geothermal energy. UNESCO, Paris, 1973; 135-148

31. Lindenmayer E (1856) Opis mineralni i lekoviti voda i njino opredelenije voobšte a ponaosob lekoviti voda u Kneževstvu Srbije dosad poznati. Praviteljstvo, Knjigopeč, Knjaž. Srbskog, Beograd

32. Leko TM, Shcherbakov A, Joksimovic MH (1922) Medicinal waters and spas. Ministry of public health, Belgrade (in Serbian)

33. Martinović M, Milivojević M (2000) The hydrogeothermal model of Mačva, Proceedings World Geothermal Congress, Kyushu-Tohoku, Japan; May 28 - June 10

34. Martinović M, Milivojević M (2010) Serbia Country Update, Proceedings World Geothermal Congress, Bali, Indonesia; April 25-29

35. Martinović M, Zlokolica-Mandić M, Vukićević Z (2010) Geothermal atlas of Vojvodina, Autonomous province of Vojvodina - Provincial Secretariat for Energy. Republic of Serbia

36. Milivojević M (1993) Geothermal model of Earth's crust and lithosphere for the territory of Yugoslavia -some tectonic implications. Stud Geophys Geod 37:265-278

37. Milivojević M, Martinović M (1996) Using of geothermal resources in the world. Ecologica, Special issue, no.3

38. Milivojević M, Martinović M (2005) Geothermal energy possibilities, exploration and future prospects in Serbia, Proceedings World Geothermal Congress, Antalya, Turkey

39. Milivojević M, Martinović M (2000) Geothermal energy possibilities, exploration and future prospects in Serbia. Proceedings World Geothermal Congress; Kyushu, Tohoku, Japan

40. Milenić $D$, Vasiljević $P$, Vranješ A (2010) Criteria for use of groundwater as renewable energy source in geotermal heat pump systems for building heating/cooling purposes, Energ Buildings 2010; 42 (5), 649-657, https://doi.org/10.1016/j.enbuild.2009.11.002

41. Miošić N, Samardžić N (2016) Mineral, Thermal and Thermomineral Waters of Bosnia and Herzegovina, in Papić P (ed.) Mineral and Thermal Waters of Southeastern Europe, Envir Earth Sci, Springer 147-171

42. Muffler LJP, Cataldi R (1978) Methods for regional assessment of geothermal resources. Geothermics 7:53-89

43. Nádor A, Lapanje A, Tóth G, Rman N, Szőcs T, Prestor J, Uhrin A, Rajver D, Fodor L, Muráti J, Székely E (2012) Transboundary geothermal resources of the Mura-Zala basin: joint thermal aquifer management of Slovenia and Hungary. Geologija doi 55(2):209-224. 10.5474/geologija.2012.013 
44. Nieva D, Nieva R (1987) Developments in geothermal energy in Mexico. XII A cationic composition geothermometer for prospection of geothermal resources. Heat Recover Syst CPH 7:243-258. https://doi.org/10.1016/0890-4332(87)90138-4

45. Oudech S, Đokić V (2015) Serbia Country Update, Proceedings World Geothermal Congress, Melbourne, Australia

46. Oudech S, Đokić V (2019) Geothermal Energy Use, Country Update for Serbia, European Geothermal Congress, Den Haag, The Netherlands

47. Ovčinkov AM (1963) Mineraljnie vodi. Izdanie vtoroe. Gosgeoltehizdat, Moskva, pp 1-375

48. Perić J, Milivojević M (1990) Study: Geothermal potential territory of Serbia without territory of Autonomous provinces. Faculty of Mining and Geology, University of Belgrade, (in Serbian)

49. Petrović Pantić T (2014) Hydrogeothermal Resources of Serbian Crystalline Core Ph.D. dissertation, Faculty of Mining and Geology, University of Belgrade 2014; p. 199 (in Serbian)

50. Petrović Pantić T, Birke M, Petrović B, Nikolov J, Dragišić V, Živanović V (2015) Hydrogeochemistry of thermal groundwaters in the Serbian crystalline core region. J Geochem Explor $n$ 159:101-114. https://doi.org/10.1016/j.gexplo.2015.08.009

51. Petrović Pantić T, Tomić M (2019) Study: Collection, updating and building database about geothermal resources of Republic of Serbia, Geological Survey of Serbia (in Serbian)

52. Porowski A (2017) Mineral and Thermal Waters. In: in Mayers (ed) Encyclopedia of Sustainability Science and Technology. Springer, https://doi.org/10.1007/978-1-4939-2493-6_978-1

53. Protić D (1995) Mineral and thermal water of Serbia, Special issue, Geoinstitute, Belgrade (in Serbian)

54. Radovanović S (1898) Groundwater, Srpska književna zadruga

55. Ristić D, Vukoičić D, Nikolić M, Milinčić N, Kićović D (2019) Capacities and energy potential of thermal-mineral springs in the area of the Kopaonik tourist region (Serbia), Renew Sust Energ Rev; 102: 129-138, https://doi.org/10.1016/j.rser.2018.12.005

56. Rman N, Gál N, Marcin D, Weilbold J, Schubert G, Lapanje A, Rajver D, Benková K, Nádor A (2015a) Potentials of transboundary thermal water resources in the western part of the Pannonian basin. Geothermics 55:88-98. https://doi.org/10.1016/j.geothermics.2015.01.013

57. Rman N, Bălan LL, Bobovečki I, Gál N, Jolović B, Lapanje A,Marković T,Milenić D,Skopljak F,RotárSzalkai A, Samardžić N, Szőcs T, Šolaja D, Toholj N, Vijdea AM, Vranješ A (2020) Geothermal sources and utilization practice in six countries along the southern part of the Pannonian basin, Envir Earth Sci 79:1, https://doi.org/10.1007/s12665-019-8746-6

58. Todorović B, Stojiljković D, Petrović Pantić T, Mitić N, Nikolić L, Cakić S (2015) Hydrogeochemistry and aragonite scaling in the Sijarinska spa (Serbia), Carbonates Evaporites, doi. 10.1007/s13146015-0266-1

59. Tóth J, Almási I (2001) Interpretation of observed fluid potential patterns in a deep sedimentary basin under tectonic compression. Geofluids 1:11-36 
60. Tóth G, Rman N, Rotár-Szalkai Á, Kerékgyártó T, Szőcs T, Lapanje A, Černák R, Remsík A, Schubert G, Nádor A (2016) Transboundary fresh and thermal groundwater flows in the west part of the Pannonian Basin. Renew Sust Energ Rev 57:439-454. https://doi.org/10.1016/j.rser.2015.12.021

61. Valjarević A, Srećković-Batoćanin D, Valjarević D, Matović V (2018) A GIS-based method for analysis of a better utilization of thermal-mineral springs in the municipality of Kuršumlija (Serbia), Renew Sust Energ Rev; 92: 948-957, https://doi.org/10.1016/j.rser.2018.05.005

\section{Tables}

Table 1. The characteristics of the type of aquifers in Serbia

\begin{tabular}{|l|l|l|l|l|}
\hline Type of aquifer & Intergranular & \multicolumn{1}{|c|}{ Karst } & Karst-fissured & \multicolumn{1}{|c|}{ Fissured } \\
\hline $\begin{array}{l}\text { Aquifer spread } \\
\text { through the } \\
\text { surface }\end{array}$ & $\begin{array}{l}\text { Northern } \\
\text { Serbia, Central } \\
\text { Serbia (river } \\
\text { valleys - } \\
\text { alluvial } \\
\text { sediments), } \\
\text { Neogene basins }\end{array}$ & $\begin{array}{l}\text { Eastern Serbia and } \\
\text { Western Serbia }\end{array}$ & Western Serbia & $\begin{array}{l}\text { Central Serbia and Eastern } \\
\text { Serbia }\end{array}$ \\
\hline $\begin{array}{l}\text { Geotectonic } \\
\text { unit }\end{array}$ & $\begin{array}{l}\text { Dominant in the } \\
\text { Pannonian } \\
\text { Basin, then in } \\
\text { Vardar Zone } \\
\text { and Serbo- } \\
\text { Macedonian } \\
\text { Massif }\end{array}$ & $\begin{array}{l}\text { Carpatho- } \\
\text { Balkanides, } \\
\text { Dinarides, western } \\
\text { part of Vardar Zone } \\
\text { (on the surface and } \\
\text { under Neogene } \\
\text { basins) }\end{array}$ & $\begin{array}{l}\text { Dinarides, } \\
\text { Vardar Zone }\end{array}$ & $\begin{array}{l}\text { Vardar Zone, Serbo- } \\
\text { Macedonian Massif and } \\
\text { Carpatho-Balkanides, }\end{array}$ \\
\hline $\begin{array}{l}\text { Dominant } \\
\text { litostratigraphic }\end{array}$ & $\begin{array}{l}\text { Alluvial } \\
\text { sediments } \\
\text { Sand, gravel, } \\
\text { marls, } \\
\text { sandstone }\end{array}$ & $\begin{array}{l}\text { Limestone, } \\
\text { dolomites }\end{array}$ & $\begin{array}{l}\text { Conglomerates, } \\
\text { sandstones, } \\
\text { marls, dolomite } \\
\text { and limestone, } \\
\text { shale, volcanic } \\
\text { rocks. }\end{array}$ & $\begin{array}{l}\text { intrusive and effusive rocks, } \\
\text { metamorphic rocks (crystalline } \\
\text { schist), and solid sediment } \\
\text { rocks (sandstone, marl, } \\
\text { conglomerate, breccia, and } \\
\text { some carbonate rocks). }\end{array}$ \\
\hline $\begin{array}{l}\text { Chemical } \\
\text { composition of } \\
\text { water }\end{array}$ & $\begin{array}{l}\text { High } \\
\text { mineralization } \\
\text { Na-HCO } \\
\text { Na-Cl and }\end{array}$ & $\begin{array}{l}\text { Low mineralization } \\
\text { Ca (Mg)-HCO }\end{array}$ & $\begin{array}{l}\text { Low } \\
\text { mineralization, } \\
\text { Ca (Mg)- HCO }\end{array}$ & $\begin{array}{l}\text { High mineralization } \\
\text { Na-HCO }\end{array}$ \\
\hline
\end{tabular}

Table 2. Utilization of geothermal resources for direct heating (modified Martinović and Milivojević; 2010; Oudech and Đokić-2015; Petrović Pantić and Tomić 2019) 


\begin{tabular}{|c|c|c|c|c|c|c|c|c|c|}
\hline Num & Locality & $\begin{array}{l}\text { Type of } \\
\text { usage }\end{array}$ & $\begin{array}{c}\text { Flow rate } \\
\mathrm{Q}(1 / \mathrm{s})\end{array}$ & $\begin{array}{c}\text { Average } \\
\text { flow Q (l/s) }\end{array}$ & $\begin{array}{c}\text { Inlet } \\
\text { temperature } \\
\left({ }^{\circ} \mathrm{C}\right)\end{array}$ & $\begin{array}{c}\text { Outlet } \\
\text { temperature } \\
\left({ }^{\circ} \mathrm{C}\right)\end{array}$ & $\begin{array}{l}\text { Capacity } \\
\text { (MWt) }\end{array}$ & $\begin{array}{l}\text { Energy } \\
\text { (TJ/yr) }\end{array}$ & $\begin{array}{l}\text { Capacity } \\
\text { factor }(n)\end{array}$ \\
\hline 1 & Ada & B & 8,6 & 3 & 61 & 25 & 1,30 & 14 & 0,35 \\
\hline 2 & $\begin{array}{l}\text { Banatsko V } \\
\text { Selo }\end{array}$ & $\mathrm{K}$ & 17,7 & 12 & 43 & 15 & 2,07 & 44 & 0,68 \\
\hline 3 & $\begin{array}{l}\text { Backi } \\
\text { Petrovac1 }\end{array}$ & B & 15 & 10 & 45 & 25 & 1,26 & 26 & 0,67 \\
\hline 4 & $\begin{array}{l}\text { Backi } \\
\text { Petrovac2 }\end{array}$ & $\mathrm{H}$ & 16,7 & 10 & 46 & 25 & 1,47 & 28 & 0,60 \\
\hline 5 & $\begin{array}{l}\text { Backi } \\
\text { Petrovac3 }\end{array}$ & A & 11 & 7 & 45 & 25 & 0,92 & 18 & 0,64 \\
\hline 6 & Bečej & $\mathrm{B}, \mathrm{H}$ & 25 & 17,2 & 65,8 & 26 & 4,16 & 90 & 0,69 \\
\hline 7 & Bezdan & B & 1,5 & 1 & 22 & 15 & 0,04 & 1 & 0,67 \\
\hline 8 & Bogatić1 & $\mathrm{H}$ & 25 & 5 & 75 & 20 & 5,75 & 36 & 0,20 \\
\hline 9 & Bogatić2 & $\mathrm{H}, \mathrm{G}$ & 17,5 & 5 & 67 & 20 & 3,44 & 31 & 0,29 \\
\hline 10 & Bogatić3 & $\mathrm{B}, \mathrm{H}$ & 40 & 25 & 79 & 55 & 4,02 & 79 & 0,62 \\
\hline 11 & Brestovačka1 & $\mathrm{B}$ & 7,5 & 3 & 41 & 30 & 0,35 & 4 & 0,40 \\
\hline 12 & Brestovačka 2 & B & 7,3 & 3 & 45,7 & 24 & 0,66 & 9 & 0,41 \\
\hline 13 & Bukovička 1 & B & 1,7 & 1 & 20,7 & 15 & 0,04 & 1 & 0,59 \\
\hline 14 & Bukovička 2 & $\mathrm{H}$ & 9 & 3 & 23 & 15 & 0,30 & 3 & 0,33 \\
\hline 15 & Bujanovačka & $\mathrm{B}, \mathrm{H}$ & 7,8 & 6,5 & 46 & 30 & 0,52 & 14 & 0,83 \\
\hline 16 & Debrc1 & $\mathrm{G}, \mathrm{H}$ & 24 & 12 & 53 & 30 & 2,31 & 36 & 0,50 \\
\hline 17 & Debrc2 & $\mathrm{G}, \mathrm{H}$ & 50 & 20 & 56 & 22 & 7,11 & 90 & 0,40 \\
\hline 18 & Dublje & $\mathrm{H}$ & 10 & 4 & 29 & 20 & 0,38 & 5 & 0,40 \\
\hline 19 & $\begin{array}{l}\text { Devojački } \\
\text { bunar }\end{array}$ & B & 20 & 7 & 26 & 25 & 0,08 & 1 & 0,35 \\
\hline 20 & Gamzigradska & $\mathrm{B}, \mathrm{H}$ & 20 & 5 & 41 & 24 & 1,42 & 11 & 0,25 \\
\hline 21 & Gornja Trepča & $\mathrm{B}, \mathrm{H}$ & 24,5 & 5 & 24,5 & 20 & 0,46 & 3 & 0,20 \\
\hline 22 & Jošanička 1 & B & 3 & 2 & 56 & 30 & 0,33 & 7 & 0,67 \\
\hline 23 & Jošanička 2 & $\mathrm{~B}$ & 1,5 & 1 & 53 & 30 & 0,14 & 3 & 0,67 \\
\hline 24 & Kanjiža1 & $\mathrm{B}, \mathrm{H}$ & 14 & 4,5 & 65 & 26 & 2,28 & 23 & 0,32 \\
\hline 25 & Kanjiža2 & $\mathrm{B}, \mathrm{H}$ & 19 & 10 & 72 & 20 & 4,13 & 69 & 0,53 \\
\hline 26 & Karađorđevo & B & 5,7 & 4 & 34 & 25 & 0,21 & 5 & 0,70 \\
\hline 27 & Kikinda1 & $\mathrm{H}$ & 6,2 & 4 & 50 & 27 & 0,60 & 12 & 0,64 \\
\hline 28 & Kikinda2 & $\mathrm{K}$ & 15,2 & 8 & 51 & 26 & 1,59 & 26 & 0,53 \\
\hline 29 & Koviljača & B & 6 & 3 & 28 & 24 & 0,10 & 2 & 0,50 \\
\hline 30 & Kula & $\mathrm{I}$ & 9,5 & 7 & 50 & 25 & 0,99 & 23 & 0,74 \\
\hline 31 & Kučura & $\mathrm{G}$ & 8,8 & 7 & 56 & 30 & 0,96 & 24 & 0,80 \\
\hline 32 & Lukovska 1 & $\mathrm{~B}, \mathrm{H}$ & 1,28 & 1 & 62 & 35 & 0,14 & 4 & 0,78 \\
\hline 33 & Lukovska 2 & $\mathrm{~B}, \mathrm{H}$ & 4,74 & 4 & 55 & 35 & 0,40 & 11 & 0,84 \\
\hline 34 & Ljig & B & 5 & 5 & 32 & 25 & 0,15 & 5 & 1,00 \\
\hline 35 & Malo Laole & B & 20 & 10 & 40,5 & 20 & 1,72 & 27 & 0,50 \\
\hline 36 & Mataruška & $\mathrm{B}$ & 15 & 5 & 48 & 36 & 0,75 & 8 & 0,33 \\
\hline 37 & Melenci & B & 2,5 & 2 & 33 & 20 & 0,14 & 3 & 0,80 \\
\hline 38 & Mokrin & $\mathrm{K}$ & 15,2 & 8 & 51 & 25 & 1,65 & 27 & 0,53 \\
\hline 39 & Nikoličevska & B & 6 & 2,8 & 34,5 & 25 & 0,24 & 4 & 0,47 \\
\hline 40 & Niška Banja & $\mathrm{B}, \mathrm{H}$ & 35 & 15 & 39,6 & 25 & 2,14 & 29 & 0,43 \\
\hline 41 & Novopazarska & $\mathrm{B}$ & 2 & 1 & 54 & 28 & 0,22 & 3 & 0,50 \\
\hline 42 & Obrenovac & $\mathrm{B}$ & 4 & 3 & 34,2 & 20 & 0,24 & 6 & 0,75 \\
\hline 43 & Ovčar Banja & $\mathrm{B}, \mathrm{H}$ & 49 & 25 & 36,5 & 25 & 2,36 & 38 & 0,51 \\
\hline 44 & Palić & B & 12,2 & 4,7 & 48 & 20 & 1,43 & 17 & 0,39 \\
\hline
\end{tabular}




\begin{tabular}{|c|c|c|c|c|c|c|c|c|c|}
\hline 45 & Pribojska1 & B & 50 & 10 & 37 & 25 & 2,51 & 16 & 0,20 \\
\hline 46 & Pribojska 2 & B & 8 & 4 & 36,5 & 25 & 0,38 & 6 & 0,50 \\
\hline 47 & Prigrevica & B & 21 & 11,8 & 53 & 20 & 2,90 & 51 & 0,56 \\
\hline 48 & Prolom & $\mathrm{B}, \mathrm{H}$ & 5,77 & 1,5 & 31 & 24 & 0,17 & 1 & 0,26 \\
\hline 49 & Radaljska & B & 6 & 4 & 23,8 & 20 & 0,10 & 2 & 0,67 \\
\hline 50 & Rajčinovića & B & 1,44 & 1 & 40,3 & 28 & 0,07 & 2 & 0,69 \\
\hline 51 & Rgoška & B & 40 & 15 & 32 & 25 & 1,17 & 14 & 0,37 \\
\hline 52 & Ribarska1 & B & 9,5 & 6 & 38,7 & 28 & 0,43 & 8 & 0,63 \\
\hline 53 & Ribarska 2 & B & 3,3 & 1,4 & 41,5 & 25 & 0,23 & 3 & 0,42 \\
\hline 54 & Ribarska 3 & $\mathrm{~B}, \mathrm{H}, \mathrm{S}$ & 5,5 & 3,5 & 26 & 21 & 0,12 & 2 & 0,64 \\
\hline 55 & Ribarska & $\mathrm{B}, \mathrm{H}$ & 9,2 & 5,8 & 54 & 31 & 0,89 & 18 & 0,63 \\
\hline 56 & $\begin{array}{l}\text { Salaš } \\
\text { Noćajski }\end{array}$ & $\mathrm{B}$ & 4,16 & 4 & 39,2 & 20 & 0,33 & 10 & 0,96 \\
\hline 57 & Sanković & B & 14 & 3 & 26,5 & 20 & 0,38 & 3 & 0,21 \\
\hline 58 & Selters & $\mathrm{B}, \mathrm{H}$ & 5 & 3 & 50 & 25 & 0,52 & 10 & 0,60 \\
\hline 59 & Sijarinska1 & B & 3 & 1,5 & 65 & 30 & 0,44 & 7 & 0,50 \\
\hline 60 & Sijarinska2 & $\mathrm{B}, \mathrm{H}$ & 33 & 5,5 & 72 & 40 & 4,42 & 23 & 0,17 \\
\hline 61 & Sijarinska3 & $\mathrm{B}$ & 4 & 2,8 & 71 & 30 & 0,69 & 15 & 0,70 \\
\hline 62 & Sisevac & B & 18 & 5 & 35,8 & 24 & 0,89 & 8 & 0,28 \\
\hline 63 & Sm. Palanka & B & 1 & 1 & 55 & 25 & 0,13 & 4 & 1,00 \\
\hline 64 & Sokobanja1 & B & 22 & 10 & 43 & 20 & 2,12 & 30 & 0,45 \\
\hline 65 & Sokobanja2 & B & 50 & 10 & 44 & 20 & 5,02 & 32 & 0,20 \\
\hline 66 & Srbobran & G & 11,6 & 6 & 64 & 24 & 1,94 & 32 & 0,52 \\
\hline 67 & Temerin1 & B & 22,4 & 6 & 40 & 35 & 0,47 & 4 & 0,27 \\
\hline 68 & Temerin2 & B & 5 & 3 & 26 & 20 & 0,13 & 2 & 0,60 \\
\hline 69 & Valjevo & $\mathrm{H}$ & 3,5 & 3 & 35 & 20 & 0,22 & 6 & 0,86 \\
\hline 70 & Vranjska 1 & $\mathrm{H}, \mathrm{G}, \mathrm{A}, \mathrm{I}$ & 56 & 15 & 80 & 50 & 7,03 & 59 & 0,27 \\
\hline 71 & Vranjska 2 & B & 2 & 1 & 80 & 30 & 0,42 & 7 & 0,50 \\
\hline 72 & Vranjska 3 & B & 1,4 & 0,5 & 93 & 30 & 0,37 & 4 & 0,36 \\
\hline 73 & Vranjska4 & B & 3,5 & 1 & 93 & 30 & 0,92 & 8 & 0,29 \\
\hline 74 & Vranjska5 & $\mathrm{H}, \mathrm{B}$ & 26,5 & 10 & 100 & 50 & 5,54 & 66 & 0,38 \\
\hline 75 & Vranjska6 & $\mathrm{H}, \mathrm{B}$ & 26,5 & 10 & 100 & 50 & 5,54 & 66 & 0,38 \\
\hline 76 & Vrbas & B & 15,8 & 10 & 55 & 25 & 1,98 & 40 & 0,63 \\
\hline 77 & Vrdnik & $\mathrm{B}, \mathrm{H}$ & 7 & 5 & 36 & 20 & 0,47 & 11 & 0,71 \\
\hline 78 & Vrnjačka & $\mathrm{B}$ & 13 & 6 & 35,3 & 20 & 0,83 & 12 & 0,46 \\
\hline 79 & Vrujci1 & B & 8,8 & 5 & 27,7 & 20 & 0,28 & 5 & 0,57 \\
\hline 80 & Vrujci2 & B & 7,5 & 5 & 27 & 20 & 0,22 & 5 & 0,67 \\
\hline \multicolumn{2}{|l|}{ Sum } & & 910,9 & & & & $\bar{~} 111,02$ & 1507 & $0,0,52$ \\
\hline
\end{tabular}

B - balneology and swimming

G - greenhouses

$\mathrm{H}$ - heating (other than heat pumps)

A - agricultural

G - greenhouse and soil heating

$\mathrm{K}$ - animal farming

I - industry

S - sanitary heat water 
Table 3. Statistic calculation for main elements in 134 water samples

\begin{tabular}{|c|l|l|l|r|r|r|r|r|r|r|r|}
\hline Aquifer & & $\mathrm{pH}$ & $\mathrm{t}$ & $\mathrm{TDS}$ & $\mathrm{Na}$ & $\mathrm{K}$ & $\mathrm{Ca}$ & $\mathrm{Mg}$ & \multicolumn{1}{l}{$\mathrm{HCO}_{3}$} & \multicolumn{1}{l}{$\mathrm{SO}_{4}$} & $\mathrm{Cl}$ \\
\hline Intergranular, & Average & 7,7 & 37,6 & 1585,9 & 501,9 & 18,6 & 70,1 & 12,3 & 1003,6 & 24,0 & 349,1 \\
$\mathrm{n}=30$ & Median & 7,9 & 31,1 & 1049,5 & 246,9 & 4,1 & 16,0 & 9,6 & 644,1 & 7,0 & 31,2 \\
& Maximum & 8,2 & 72,0 & 4161,6 & 1780,0 & 230,0 & 830,0 & 42,1 & 2928,0 & 128,0 & 1906,9 \\
& Minimum & 6,6 & 21,8 & 327,5 & 8,3 & 0,7 & 1,6 & 0,9 & 12,4 & 0,0 & 0,3 \\
& Range & 1,6 & 50,2 & 3834,1 & 1771,7 & 229,3 & 828,4 & 41,2 & 2915,6 & 128,0 & 1906,7 \\
\hline Frissured, & Average & 7,3 & 41,6 & 2149,4 & 679,3 & 23,8 & 67,1 & 26,6 & 1650,8 & 140,1 & 176,4 \\
$\mathrm{n}=45$ & Median & 7,1 & 33,8 & 1305,2 & 398,0 & 14,5 & 44,0 & 16,5 & 1050,0 & 25,0 & 35,0 \\
& Maximum & 9,4 & 111,0 & 6857,9 & 2445,0 & 89,3 & 405,0 & 110,0 & 3950,0 & 2550,0 & 4080,0 \\
& Minimum & 6,5 & 20,5 & 149,6 & 4,6 & 0,2 & 1,9 & 0,0 & 97,0 & 1,1 & 0,5 \\
& Range & 2,9 & 90,5 & 6708,3 & 2440,4 & 89,1 & 403,1 & 110,0 & 3853,0 & 2548,9 & 4079,5 \\
\hline Karst & Average & 7,2 & 32,7 & 467,9 & 59,9 & 3,8 & 75,8 & 21,0 & 427,8 & 29,2 & 19,4 \\
n=37 & Median & 7,1 & 28,0 & 384,3 & 17,0 & 3,0 & 75,1 & 17,6 & 395,0 & 10,0 & 10,7 \\
& Maximum & 8,4 & 79,0 & 1402,6 & 252,0 & 15,7 & 234,5 & 86,0 & 1420,0 & 148,0 & 124,0 \\
& Minimum & 6,4 & 20,0 & 192,7 & 1,2 & 0,3 & 12,6 & 2,6 & 24,0 & 0,7 & 0,5 \\
& Range & 2,0 & 59,0 & 1209,9 & 250,8 & 15,4 & 221,9 & 83,4 & 1396,0 & 147,3 & 123,5 \\
\hline Karst-- & Average & 7,3 & 31,2 & 390,5 & 32,4 & 2,8 & 72,2 & 18,5 & 356,2 & 14,7 & 25,1 \\
nissured, & Median & 7,3 & 24,0 & 320,4 & 6,3 & 1,1 & 71,4 & 15,9 & 305,9 & 7,9 & 14,8 \\
& Maximum & 7,8 & 68,0 & 1194,3 & 309,6 & 23,6 & 107,8 & 36,0 & 961,0 & 82,0 & 91,3 \\
& Minimum & 7,0 & 21,0 & 239,4 & 1,1 & 0,1 & 41,2 & 5,0 & 250,0 & 1,4 & 2,8 \\
& Range & 0,8 & 47,0 & 954,9 & 308,5 & 23,5 & 66,6 & 31,0 & 711,0 & 80,6 & 88,5 \\
\hline
\end{tabular}

Table 4. Pearson correlation coefficients between TDS and main cations and anions in thermal water samples from a different type of aquifer.

\begin{tabular}{|l|l|l|l|l|l|l|l|}
\hline & \multicolumn{7}{|c|}{ Pearson coefficients TDS vs. } \\
\hline Aquifer & $\mathrm{Ca}$ & $\mathrm{Mg}$ & $\mathrm{Na}$ & $\mathrm{K}$ & $\mathrm{HCO}_{3}$ & $\mathrm{Cl}$ & $\mathrm{SO}_{4}$ \\
\hline intergranular & 0.21 & -0.08 & $\mathbf{0 . 8 5}$ & 0.28 & 0.63 & $\mathbf{0 . 7 6}$ & -0.27 \\
\hline fissured & 0.44 & 0.164 & $\mathbf{0 . 9 8}$ & 0.66 & $\mathbf{0 . 7 5}$ & 0.42 & 0.55 \\
\hline karst & 0.37 & 0.67 & $\mathbf{0 . 7 8}$ & 0.58 & $\mathbf{0 . 9 4}$ & 0.01 & 0.59 \\
\hline karst-fissured & -0.02 & -0.03 & $\mathbf{0 . 9 6}$ & $\mathbf{0 . 9 7}$ & $\mathbf{0 . 9 8}$ & $\mathbf{0 . 8 8}$ & $\mathbf{0 . 9 3}$ \\
\hline
\end{tabular}

Table 5. Statistic values of estimated temperatures of geothermal resources in Serbia, calculated using $\mathrm{SiO}_{2}, \mathrm{Na}-\mathrm{K}$, and K-Mg geothermometers 


\begin{tabular}{|c|c|c|c|c|c|c|c|c|c|c|c|c|}
\hline Aqu & & q 1 & Eq 2 & Eq 3 & Eq 4 & Eq 5 & Eq 6 & Eq 7 & Eq 8 & Eq 9 & Eq 10 & Eq 11 \\
\hline & & \multicolumn{4}{|c|}{ quartz } & \multicolumn{2}{|c|}{ chacedon } & \multicolumn{4}{|c|}{$\mathrm{Na}-\mathrm{K}$} & $\mathrm{K}-\mathrm{Mg}$ \\
\hline \multirow{5}{*}{$\begin{array}{c}\text { Intergranular, } \\
\mathrm{n} \mathrm{SiO}_{2}=10 \\
\text { n cation }=30\end{array}$} & & 68,3 & 68,3 & 67,9 & 67,4 & 39,9 & 36,7 & 115,3 & 84,5 & 95,2 & 66,8 & 26,7 \\
\hline & edian & 76,5 & 76,5 & 77,0 & 77,4 & 47,9 & 45,0 & 98,6 & 67,4 & 77,6 & 46,1 & 24,9 \\
\hline & Max & 107,3 & 107,3 & 107,6 & 107,2 & 78,6 & 77,7 & 204,0 & 174,2 & 187,3 & 172,0 & 64,7 \\
\hline & Min & 27,8 & 27,8 & 24,5 & 21,5 & 0,1 & $-5,1$ & 15,6 & $|-13,3|$ & $-5,3$ & $-39,7$ & $-2,5$ \\
\hline & Range & 79,5 & 79,5 & 83,1 & 85,7 & 78,6 & 82,8 & 188,4 & 187,5 & 192,6 & 211,7 & 67,2 \\
\hline \multirow{5}{*}{$\begin{array}{c}\text { Frissured, } \\
\text { n SiO }_{2=} 34, \\
\text { n cation }=45\end{array}$} & rerage & 102,1 & 102,1 & 102,4 & 101,4 & 73,7 & 72,6 & 172,1 & 142,1 & 154,3 & 135,0 & 48,4 \\
\hline & Median & 103,3 & 103,3 & 103,7 & 103,6 & 74,7 & 73,5 & 171,0 & 140,3 & 152,5 & 130,3 & 52,2 \\
\hline & Max & 146,2 & 146,2 & 146,3 & 141,7 & 118,1 & 120,5 & 311,8 & 288,8 & 304,6 & 325,1 & 100,1 \\
\hline & Minimum & 39,3 & 39,3 & 37,7 & 36,0 & 11,2 & 6,5 & 62,4 & 31,8 & 41,1 & 7,4 & $-8,2$ \\
\hline & Range & 106,9 & 106,9 & 108,7 & 105,7 & 106,9 & 113,9 & 249,4 & 256,9 & 263,5 & 317,8 & 108,3 \\
\hline \multirow{5}{*}{\begin{tabular}{l}
\multicolumn{1}{c}{ Karst } \\
N SiO2=19, \\
n cation=37
\end{tabular}} & Average & 66,1 & 66,1 & 65,8 & 65,1 & 37,8 & 34,5 & 244,7 & 219,0 & 233,1 & 238,0 & 10,2 \\
\hline & Median & 61,1 & 61,1 & 61,2 & 61,2 & 32,7 & 29,0 & 234,9 & 206,5 & 220,4 & 213,1 & 9,6 \\
\hline & Max & 115,2 & 115,2 & 115,5 & 114,5 & 86,7 & 86,4 & 463,5 & 460,0 & 479,6 & 598,9 & 45,0 \\
\hline & Iin & 39,3 & 39,3 & 37,7 & 36,0 & 11,2 & 6,5 & 73,9 & 43,1 & 52,7 & 19,5 & $-37,2$ \\
\hline & Range & 76,0 & 76,0 & 77,8 & 78,5 & 75,4 & 79,8 & 389,6 & 416,9 & 426,9 & 579,5 & 82,2 \\
\hline \multirow{5}{*}{$\begin{array}{c}\text { Karst--fissured, } \\
\text { n SiO2=12, } \\
\text { n cation }=21\end{array}$} & Average & 58,5 & 58,5 & 57,9 & 57,1 & 30,2 & 26,4 & 249,8 & 223,2 & 237,5 & 238,6 & $-1,5$ \\
\hline & Median & 51,5 & 51,5 & 51,1 & 50,5 & 23,3 & 19,1 & 234,0 & 205,6 & 219,4 & 211,9 & $-3,6$ \\
\hline & Max & 101,8 & 101,8 & 102,2 & 102,2 & 73,2 & 71,9 & 359,1 & 340,9 & 358,0 & 402,3 & 56,0 \\
\hline & & 32,6 & 32,6 & 30,1 & 27,7 & 4,7 & $-0,2$ & 132,0 & 100,7 & 111,8 & 83,7 & $-39,0$ \\
\hline & Range & 69,2 & 69,2 & 72,1 & 74,4 & 68,4 & 72,1 & 227,2 & 240,2 & 246,1 & 318,5 & 95,0 \\
\hline
\end{tabular}

\section{Figures}




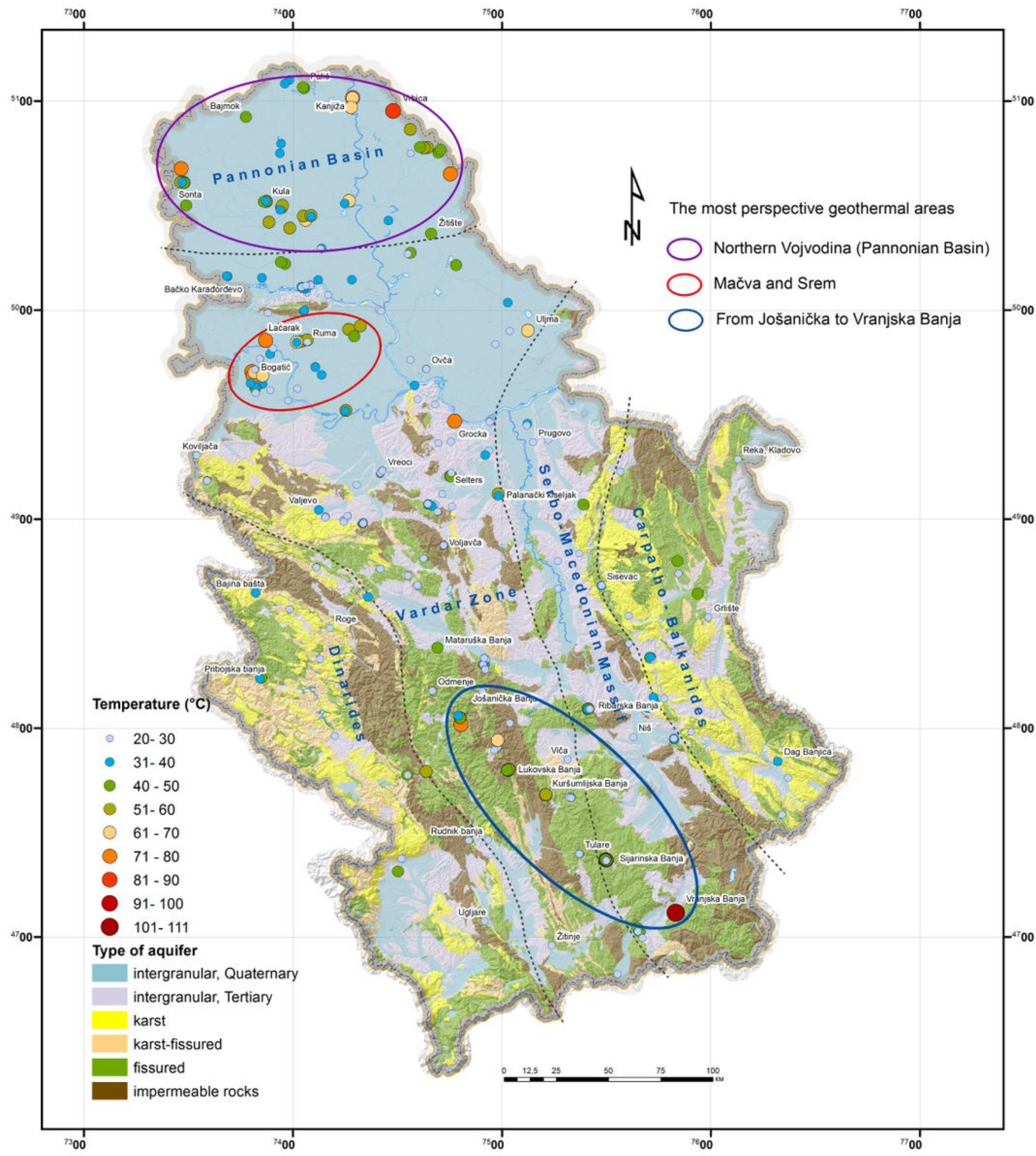

Figure 1

Hydrogeological map of Serbia with the most perspective geothermal areas and distribution of thermal waters 


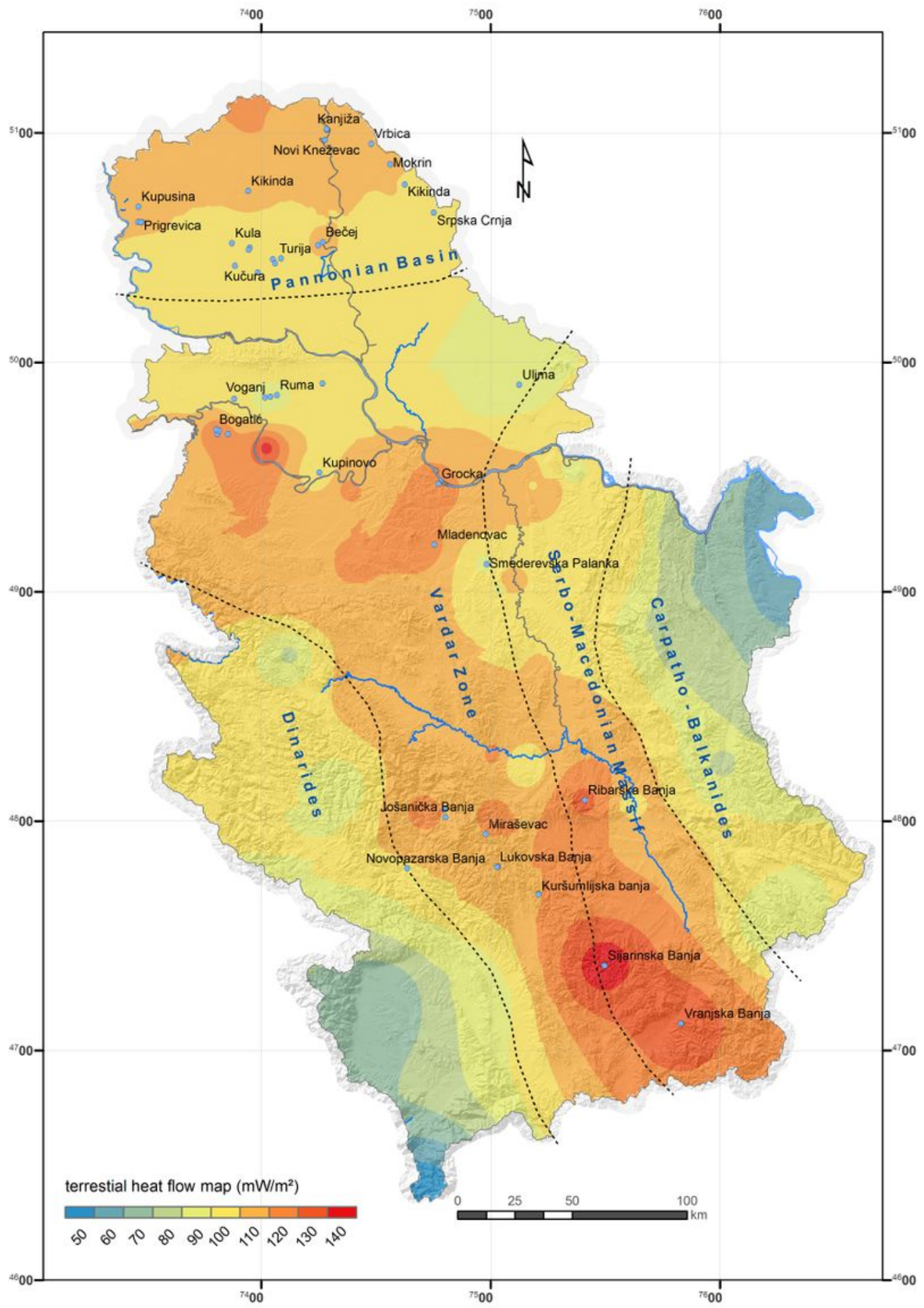

\section{Figure 2}

Terrestrial Heat Flow Density map of Serbia (modified Milivojević and Martinović, 2005 and Martinović et al,. 2010) with boreholes/springs with water temperature higher than $50^{\circ} \mathrm{C}$. The main geotectonic units are presented on the map. 


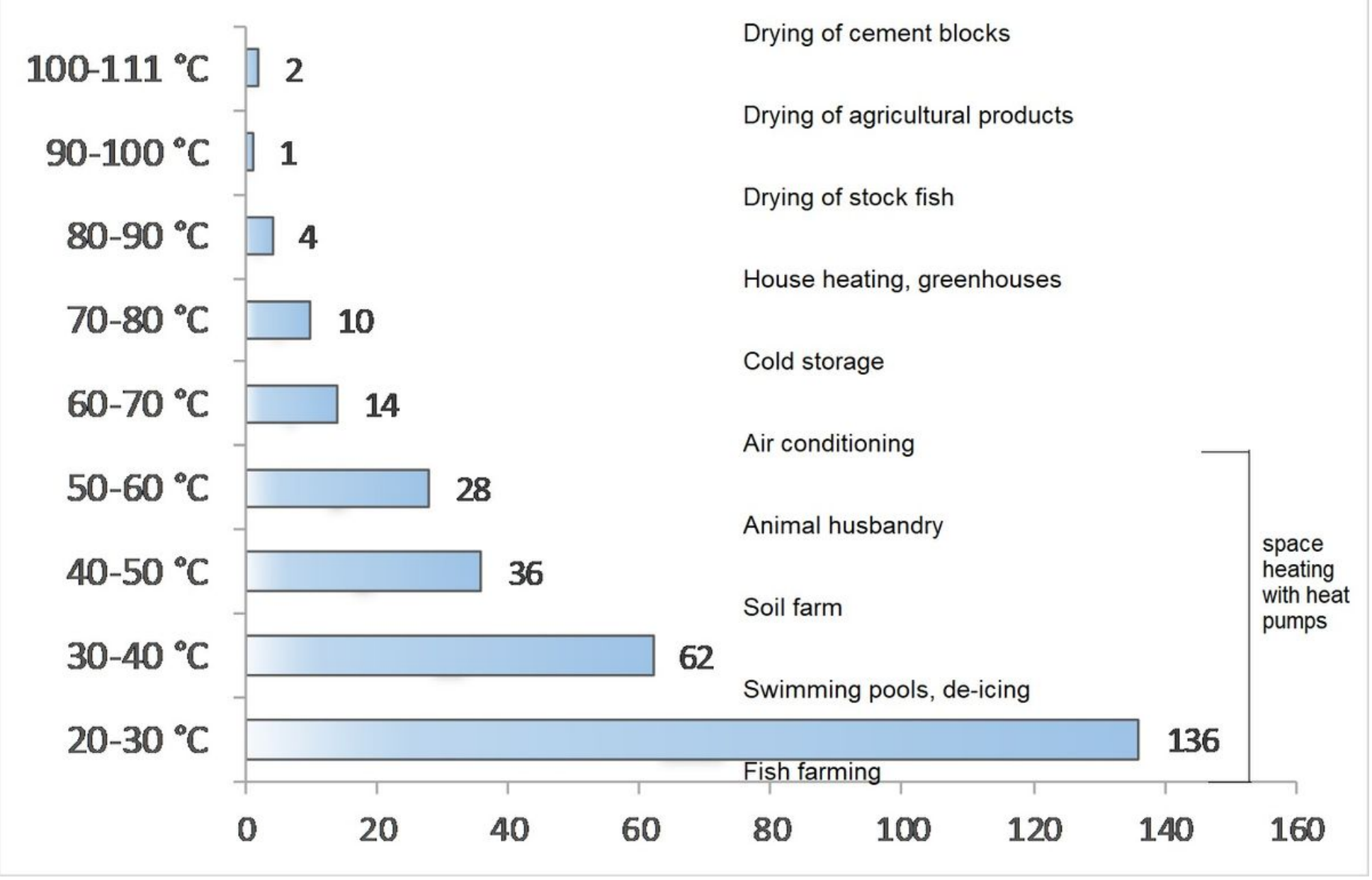

\section{Figure 3}

The number of springs/wells in Serbia according to the groundwater temperature in correlation with their possibility of use (according to Lindal diagram (Lindal, 1973)) 


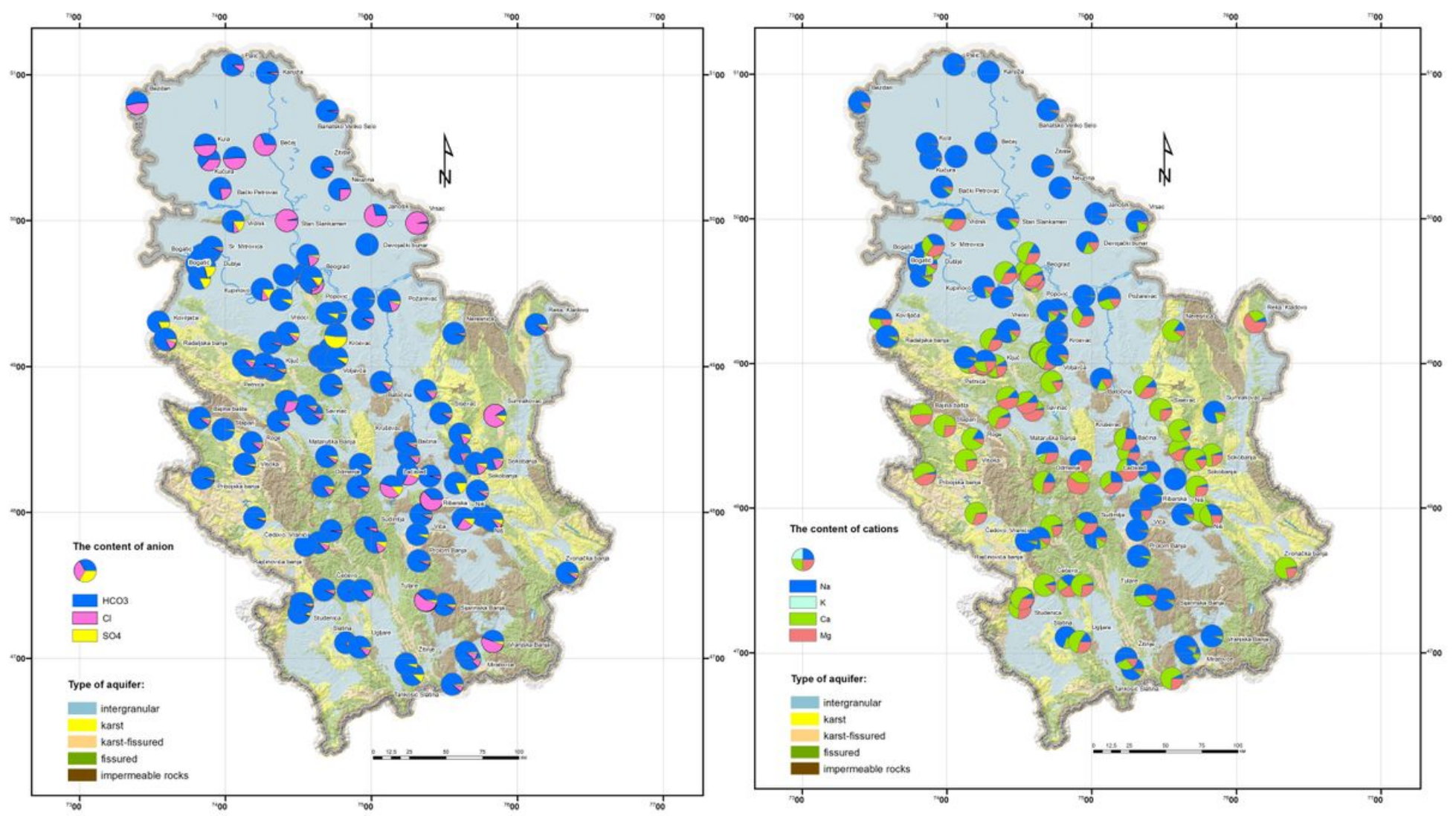

Figure 4

Spatial distribution of anions Left:(a) and cations Right: (b) in thermal waters in Serbia

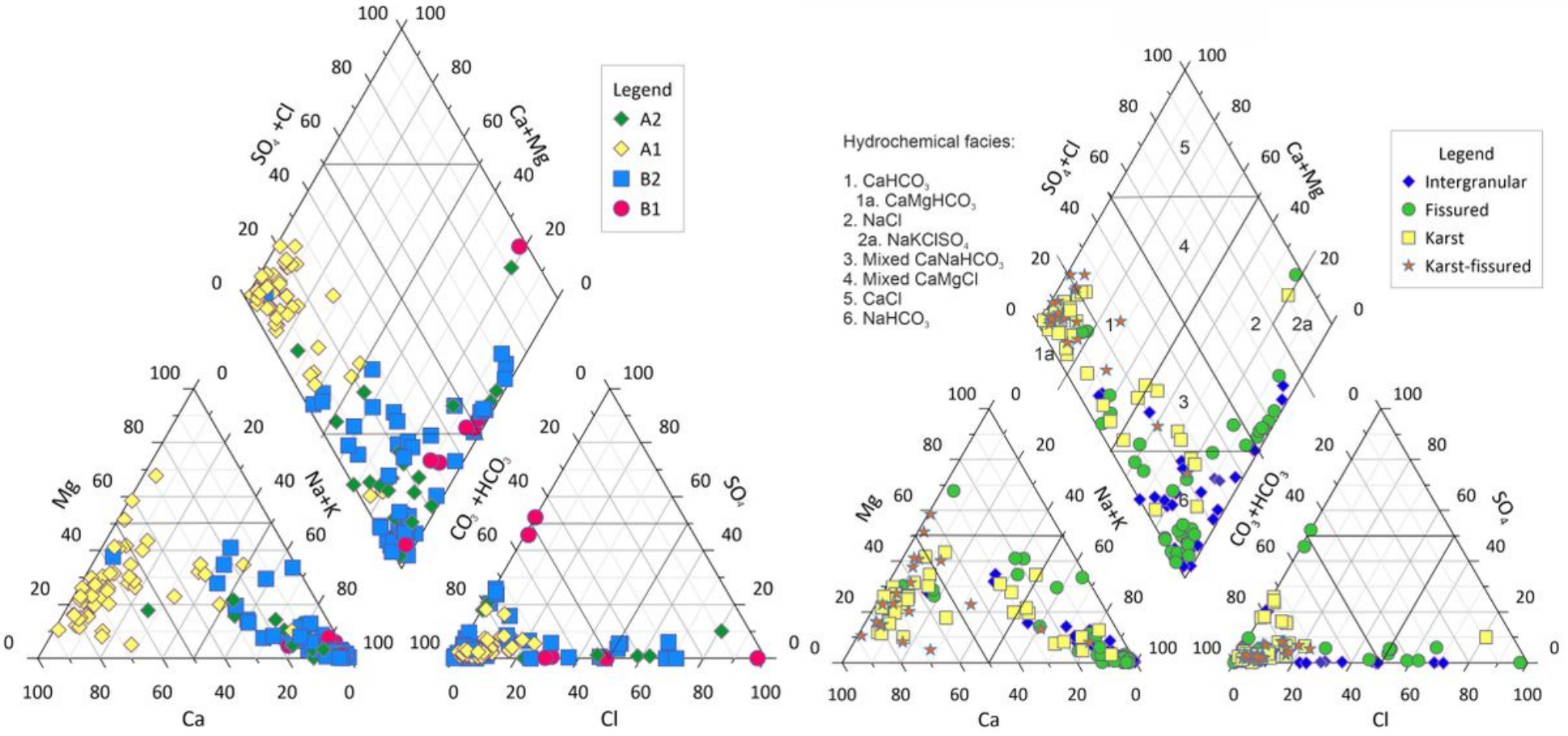

Figure 5 
Piper trilinear diagram of thermal waters of Serbia according to Cluster analysis Left: (a), and according to type of aquifer Right:(b)

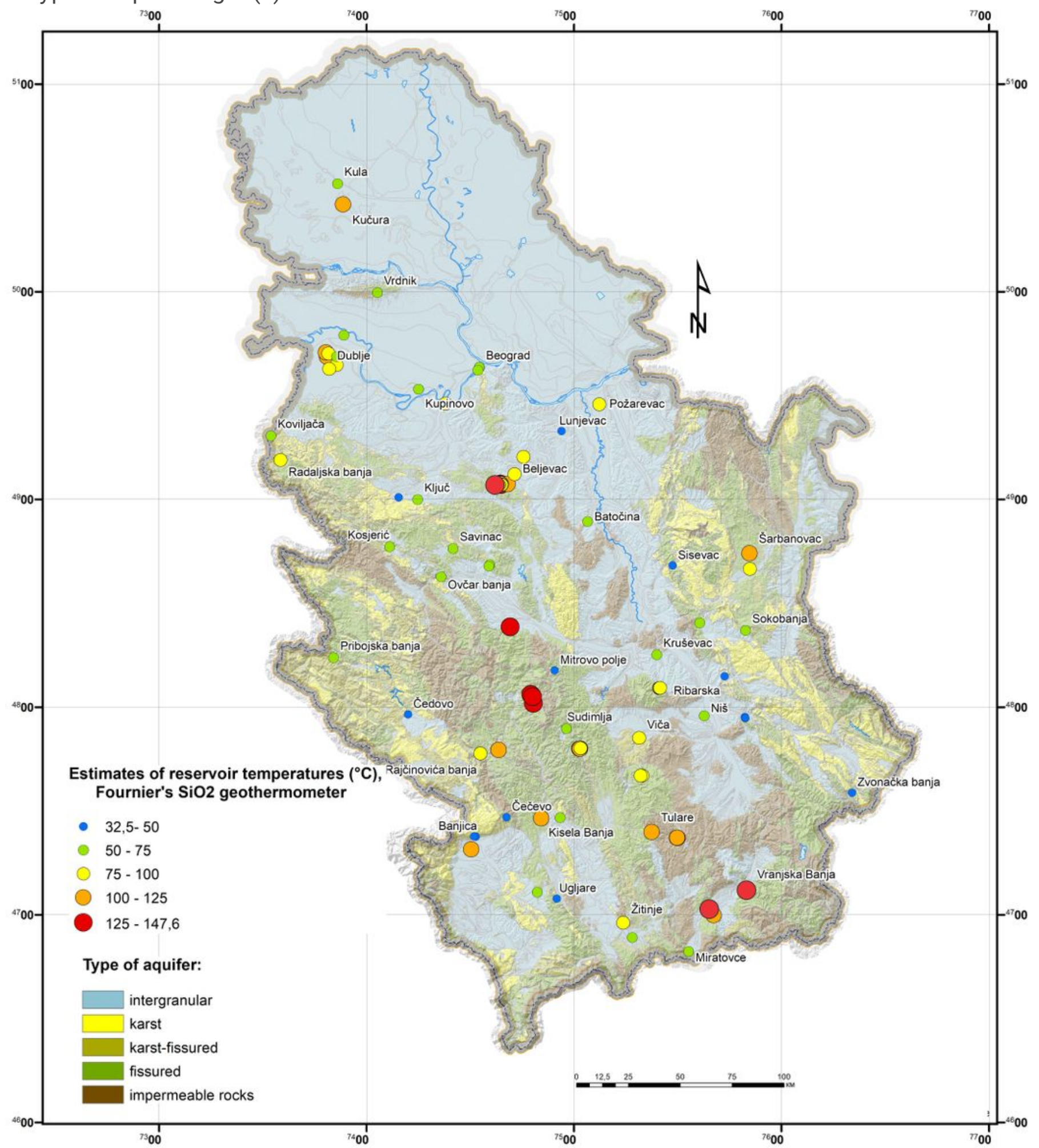

Figure 6

Temperature distribution calculated from silica geothermometer using eq 1. 


\section{Image not available with this version}

\section{Figure 7}

$\mathrm{Na}-\mathrm{K}-\mathrm{Mg} 0.5$ triangular diagram of thermal resources of Serbia (cross symbol represent colder water with $\mathrm{T}<30^{\circ} \mathrm{C}$ and circles represent resources with $\mathrm{T}>30^{\circ} \mathrm{C}$ ) 